Criação / Fotografia 



\title{
A imagem incomum: a fotografia dos atos de fé no Brasil ${ }^{*}$
}

\author{
JOSÉ DE SOUZA MARTINS
}

\section{Reflexões introdutórias sobre uma sociologia do conhecimento visual}

A FOTOGRAFIA, na perspectiva sociológica ou antropológica, sabemos, não esgota as possibilidades cognitivas nos temas cuja visualização permite (1). Por trás da fotografia, mesmo aquela com intenção documental, há uma perspectiva do fotógrafo, um modo de ver que está referido a situações e significados que não são diretamente próprios daquilo que está sendo fotografado e daqueles que estão sendo fotografados, mas referido à própria e peculiar inserção do fotógrafo no mundo social. Sem contar, obviamente, as limitações propriamente técnicas da fotografia, que chegam a ter repercussões culturais duradouras. Um bom exemplo é que nas populações sertanejas do Brasil ainda hoje, mesmo em face de câmeras ultra-rápidas, as pessoas se perfilam diante da máquina, o corpo enrijecido, a respiração contida. Algo que, a rigor, nada tem a ver com a fotografia na atualidade, mas é de fato memória de um tempo em que a fotografia dependia de exposições longas e até de poses pré-determinadas. Freqüentemente, o fotografado tinha que contar com o apoio de algum meio disfarçado, como a cadeira de espaldar alto, um poste, uma parede, um portão, para manter-se imóvel pelo longo tempo necessário ao ato de fotografar.

Mas há também dimensões, significações e determinações ocultas na realidade fotografada. O verossímil não é necessariamente o verdadeiro e, certamente, não é o concreto, embora seja o real. Por seu lado, ao fotografar, o fotógrafo imagina. Também o sociólogo e o antropólogo, ao fotografar, imaginam, do mesmo modo que imaginam quando fazem suas outras formas de registro, mesmo que se possa e até se deva pensar numa imaginação fotográfica (ou numa imaginação sociológica, como propõe C. Wright Mills) (2). De Margareth Mead a Oscar Lewis, a história do trabalho antropológico registra e reconhece vários episódios e orientações imaginativas, de natureza valorativa, que afetaram os rumos de observações e descobertas.

* Trabalho apresentado no Symposium on Popular Religion and Visual Culture in Brazil, organizado pelo Centre for Brazilian Studies e pelo Pitt Rivers Museum, da Universidade de Oxford (Inglaterra), no Ashmolean Museum, em $1^{\circ}$ de fevereiro de 2002. 
A imaginação fotográfica envolve um modo de produção de imagens fotográficas, a composição e a perspectiva, o apelo a recursos técnicos para escolher e definir a profundidade de campo, enfim um modo de construir a fotografia, de juntar no espaço fotográfico o que da fotografia deve fazer parte e o modo como deve fazer parte. O chamado "congelamento" do instante fotográfico é, na verdade, a redução das desencontradas temporalidades contidas nos diferentes componentes da composição fotográfica a um único e peculiar tempo, o tempo da fotografia.

É nessa construção, nessa redução dos tempos da realidade social ao espaço da imagem fotográfica e ao seu tempo aparentemente único, que o fotógrafo imagina, isto é, constrói a sua imagem fotográfica, aquilo que quer dizer através da fotografia. Mas, das expressões de um rosto aos elementos simbólicos do vestuário e da circunstância da fotografia, inevitavelmente agregam-se à imagem fotográfica os decodificadores que a "descongelam", isto é, que revelam a dimensão sociológica e antropológica do que foi fotografado. Se a fotografia aparentemente "congela" um momento, sociologicamente, de fato, ela "descongela" esse momento ao remetê-lo para a dimensão da história, da cultura e das relações sociais. O "congelar" não é mais do que o sublinhar elementos de referência de um imaginário cujo âmbito não se restringe ao reducionismo dos supostos "congelamentos". O pressuposto de que a fotografia é um ato de "congelamento" não é mais do que ideologia do ato fotográfico, algo bem distante da apreciação propriamente científica do que é a fotografia.

Os fotografados também imaginam, e se imaginam, e são agentes e personificações das estruturas e dos processos sociais de que têm apenas uma compreensão imaginária ou, simplesmente, ideológica.

Portanto, decifrar o que se esconde por trás do visível (e do fotografável) continua sendo um desafio para os cientistas que se documentam com expressões visuais da realidade social. Um desafio, sobretudo, de natureza metodológica. Talvez as coisas fiquem um pouco mais fáceis se pudermos lidar com a documentação visual, e especialmente com a fotografia, enquanto meio de compreensão imaginária da sociedade e abrirmos mão, de vez, da ilusão de haver na fotografia um documento socialmente realista e objetivo (3). As fantasias, as ilusões, as distorções, os equívocos de interpretação de senso comum, as expressões de "falsa consciência" ou de auto-engano também são documentos relevantes para as ciências sociais, para o estudo das mentalidades e das relações entre consciência social e relações sociais. Até porque outras tantas fantasias entram cotidianamente no jogo dos relacionamentos sociais face-a-face, até de modo mais ou menos consciente (4). É nesse jogo que os processos interativos são surpreendidos e analisados pelo sociólogo - jogo que é a encenação, o relacionamento apoiado no imaginário, como premissa do ato de desvendamento próprio do conhecimento sociológico, que dele difere e a ele se opõe.

Mesmo que consigamos fazer uma etnografia dos elementos da composição fotográfica e consigamos, portanto, desconstruir os tempos da fotografia 
para chegar à realidade social que ela pretende documentar, estaremos em face de algo que é outra coisa, diversa daquilo que "estava lá" no momento do ato fotográfico. Teremos que admitir que essa realidade não é mais ela mesma e sim uma realidade mediada pelo tempo da fotografia, pelo olhar e pela situação social do próprio fotógrafo, por aquilo que ele socialmente representa e pensa - isto é, pelas ênfases que na composição decorrem do ato fotográfico, pelos objetos e temas que, desse modo, são colocados no horizonte visual da sociedade e de seus membros. Com a fotografia, a sociedade passa a ver mais e a ver menos ao mesmo tempo, porque passa a ver através da mediação de um instrumento técnico da sociedade racional e moderna.

No entanto, eu não diria que a fotografia de interesse sociológico possa ser considerada híbrida combinação de ficção e realidade. O ilusório é sociologicamente mediação constitutiva do real. A questão tem sido, portanto, para os sociólogos, ou reconhecer-lhe a legitimidade ou rejeitá-la como documento social. A câmera fotográfica dota a sociedade moderna de um instrumento de produção de uma consciência visual própria e característica da modernidade: racionaliza e tecnifica a produção da imagem, ampliando a possibilidade da consciência fantasiosa e, ao mesmo tempo, libertadora nos cerceamentos do mundo da razão e da técnica. Mas é uma consciência fantasiosa limitada a um eixo de referência, que é a própria sociedade e sua dinâmica de tensa disputa entre produção e reprodução das relações sociais (5). Portanto, uma consciência fantasiosa constitutiva do real e do que supomos socialmente objetivo, a representação de uma sociedade que oculta e domestica sob a razão e a racionalização algumas de suas necessidades fundamentais de expressão, de emoção, de criação e de vivência (6).

A suposta pureza virginal da sociedade observada se perde no ato fotográfico, ao mesmo tempo em que se enriquece com a luz que advém dessas mediações e interveniências. Nesse sentido, perdem-se as ciências sociais no falso dilema da distinção entre fotografia documental e fotografia artística. Não só porque pode haver uma indiscutível dimensão artística na fotografia documental, como na obra fotográfica de Sebastião Salgado ou de Pierre Verger (7), como obviamente há uma indiscutível dimensão documental na fotografia artística.

A insistência nessa fratura limita e empobrece o campo da sociologia visual, o que se tornará cada vez mais grave na medida em que o amadorismo fotográfico, uma fonte documental de importância crescente na sociologia, estará cada vez mais marcado por orientações estéticas e por um deliberado aperfeiçoamento estético do ato fotográfico. Algo cada vez mais distante da ingênua fotografia popular estudada há alguns anos por Pierre Bourdieu e sua equipe (8).

Para o sociólogo, o importante da fotografia está no imaginário social de que ela é meio, na imaginação mediadora que suscita. O sociólogo "lê" a fotografia indiretamente, através da compreensão que dela tem o homem comum, da interpretação da vida social e da consciência social de que ela é instrumento e expressão. A sociologia visual poderia ser também e, talvez, sobretudo uma socio- 
logia do conbecimento visual, sociologia de um modo de conhecer visualmente a sociedade e suas relações sociais e um modo de conhecer a consciência social e os meios e modos cada vez mais diversificados de sua expressão.

A leitura popular da fotografia, a leitura que dela faz o homem comum e cotidiano, se propõe, sobretudo em seus usos, nas formas espontâneas de interpretá-la, nos comentários que suscita, nas recordações que viabiliza, na vivência que promove (9). Na concepção popular da fotografia, a sociedade se projeta, se propõe interpretativamente. Essa não é a única leitura possível da fotografia, mas do ponto de vista sociológico é a que se poderia definir como leitura documental $\mathrm{e}$, portanto, uma das matérias-primas do conhecimento relativo à construção social da realidade. Refiro-me, particularmente, à sociologia centrada nos processos interativos e na relevância da mediação simbólica que neles há, uma sociologia que reconhece a eficácia da dimensão fenomênica nos relacionamentos e na consciência social. Portanto, uma sociologia fundada no pressuposto de que a sociedade se propõe à interpretação sociológica como estrutura social e como processo cognitivo ao mesmo tempo. O que pede uma sociologia do conhecimento de senso comum, na concepção de Berger e Luckmann (10), e mesmo uma sociologia do conhecimento na concepção clássica de Karl Mannheim (11).

\section{O visível e o invisível na religiosidade popular brasileira}

Neste texto, não me proponho a fazer apenas uma interpretação, uma leitura de fotografias relativas ao mundo da fé, nem a fazer apenas uma reflexão sobre o uso documental da fotografia em relação ao tema da exposição Acts of Faith, que reúne trabalhos de cinco conhecidos fotógrafos brasileiros (12). Entendo que não se pode pensar a fotografia, nesses casos, sem pensar o objeto da fotografia e, também, pensar o objetivo da fotografia. Uso, objeto e objetivo da fotografia são temas inter-relacionados.

O tema proposto pela exposição é, nessa perspectiva, particularmente rico de sugestões e desafios antropológicos e também sociológicos (13). A obra dos cinco autores expostos trata de um dos aspectos mais complexos e mais desafiadores da cultura brasileira - a religião popular, em especial o catolicismo popular e suas manifestações, suas práticas, o imaginário que lhe dá sentido e de que é parte (14). Não é raro que se veja em documentação assim a evidência de um certo folclorismo ingênuo do povo e, para muitos, até um certo atraso, evidência de uma recusa em aceitar o inevitável mundo moderno. Minha compreensão vai contra essa tendência ainda muito forte no Brasil, não só nos círculos letrados, mesmo nos meios acadêmicos, mas também nas organizações políticas.

Ouvi há alguns anos, no sertão do centro-oeste do Brasil, uma devota cantando um belíssimo bendito aprendido em Bom Jesus da Lapa, na Bahia, centro de romaria de que há fotografias nessa exposição. Lembro de uma estrofe desse canto devocional e litúrgico:

Bendito e louvado seja

Nosso Senhor da Pobreza. 
Se o pobre não trabalhar,

$\mathrm{O}$ rico não tem nobreza.

Nada menos idílico e folclórico do que essa expressão de uma devoção religiosa atravessada por uma consciência clara das diferenças sociais e das raízes sociais da pobreza. Uma consciência ainda referida, tanto tempo depois, ao caráter estamental da diferenciação social na Colônia: as diferenças sociais são apreendidas a partir da postura soberba dos ricos, numa época, persistente aliás, em que a postura, isto é, o dar-se a ver, era momento constitutivo e essencial da hierarquia social. Uma evidência não só de uma certa consciência da estratificação social, mas também da enorme relevância do ver e do visível na ordenação dos estamentos - o que tem sentido numa sociedade em que a ostentação era parte dos meios de dominação. Uma ostentação que acercava vivos e mortos do altar-mor das igrejas, como se vê na ordem dos sepultamentos nos templos católicos: mais perto do sacrário, e de Deus ali simbolizado, os mais ricos e poderosos. Portanto, uma ostentação que, de algum modo, era um regalo divino, próprio dos puros de sangue e puros de fé. Marcas de ostentação que faziam de um rico um cavaleiro calçado e do pobre um peão descalço, formas visíveis da diferenciação social. As diferenças sociais tinham que ser vistas para serem legítimas, algo que permanece na cultura brasileira até hoje. Por isso mesmo, a transgressão no dar-se a ver, o fazer-se ver com a máscara do outro, do que domina, tem sido uma forma politicamente imperceptível de protesto social dos pobres. Uma espécie de inversão carnavalesca das identidades, uma inversão alegórica.

$\mathrm{O}$ ver e o ver-se ficaram inscritos profundamente na realidade das relações sociais e, sobretudo, da consciência religiosa, como um poderoso resquício da fé e do ordenamento social barrocos. Um modo de vida que distinguia os que tinham estilo (e direito a tê-lo) dos que não o tinham. Não é estranho, portanto, que a difusa e lenta insurgência popular no Brasil inclua a captura da ostentação dos ricos pelos pobres, como se vê em fotos das devotas da Irmandade da Boa Morte, em Cachoeira, na Bahia, ostentando a estola sacerdotal do padre católico. E se vê, também, em várias fotos de Tiago Santana em que aparecem beatos e beatas vestidos improvisadamente de frades, padres e monjas (15). Uma captura de um fundamental equipamento de identificação do estamento sacerdotal, com o forte significado de uma transfiguração simbólica e imaginária.

Nela a ordem social aparece invertida, revertida através de equipamentos de identificação que transladam os humilhados e ofendidos para o âmbito do sagrado, redimindo-os simbolicamente da humilhação de sua subalternidade (16). Não é casual, pois, que as mais significativas rebeliões populares na história brasileira tenham sido, e de certo modo continuem sendo, ao mesmo tempo, um mergulho dos pobres no sagrado, na sacralidade plena. Um arrebatamento, mais do que uma efetiva revolta. Um justiçamento imaginário levado a cabo pelos pobres e injustiçados. Expressão de uma consciência social de que a injustiça é constitutiva da sociedade que a eles se propõe de cabeça para baixo, invertida 
pelo Maligno, que é o senhor da riqueza, dos bens materiais, dos poderes e de todas, assim popularmente concebidas, aberrações sociais. Neste caso, através de vestes e adornos, de o que identifica os agentes do sagrado, há o intento da captura do poder do trato com o sagrado, mediação essencial na construção do mundo colonial, como privilégio e monopólio dos sacerdotes consagrados.

As grandes revoltas populares no país têm estado profundamente marcadas pela mediação das crenças religiosas das populações camponesas. Mesmo nos últimos cinqüenta anos, em que o país passou por grandes transformações sociais e políticas, e sofreu acentuada e generalizada modernização, os milhares de conflitos sociais envolvendo comunidades camponesas só podem ser compreendidos se levarmos em conta que a motivação religiosa tem aí desempenhado uma função central.

A migração de milhares de pessoas do nordeste e do centro-oeste para a Amazônia, a partir dos anos 50 e até hoje, lugar de numerosos conflitos camponeses, tem sido concebida pelos próprios migrantes como uma imensa romaria em direção à terra prometida. No mais das vezes, devotos do padre Cícero deslocam-se em busca da mítica Bandeira Verde, cuja existência ele teria mencionado em suas profecias, vulgarizadas em folhetos de cordel. Tudo indica que a concepção utópica resulta de uma mescla de crenças medievais que reúne as idéias de Gioacchino da Fiore sobre a Terceira Era, o tempo do Divino Espírito Santo, com o imaginário das cruzadas e das peregrinações à Terra Santa (17).

Eu mesmo ouvi, de um grupo desses migrantes joaquimitas na Amazônia, a explicação de que seguiam o rumo da Via Láctea, especialmente visível no Brasil central em certas épocas do ano, o Caminho de Santiago (o caminho de Saint Jacques, o caminho dos peregrinos de Santiago de Compostela, e referência das "jacqueries" - as revoltas camponesas - na Europa). Essas crenças se difundiram no Brasil na época da Conquista e são até hoje um dos fundamentos da religiosidade popular no país. Portanto, há nelas um certo milenarismo e um certo messianismo, não raro associados, ainda, à esperança no retorno do jovem rei Dom Sebastião, de Portugal, morto no século XVI na guerra contra os mouros. Morte que custou ao reino a anexação à coroa da Espanha por um período de sessenta anos. O maior escritor sacro do Brasil e do então reino de Portugal, o padre Antônio Vieira, foi joaquimita e sebastianista, razão pela qual chegou a ser processado pela Inquisição (18).

As duas maiores guerras sertanejas do país, a de Canudos, na Bahia (18961897), e a do Contestado, em Santa Catarina (1912-1916), foram revoltas de inspiração joaquimita e sebastianista. Nas duas, a igreja Católica apoiou o Estado e se pôs contra os camponeses, que supunha heréticos. $\mathrm{O}$ maior e mais ativo movimento camponês do Brasil, na atualidade, quase um partido político, o Movimento dos Trabalhadores Rurais sem Terra (MST), nasceu no interior da igreja Católica. Nasceu em grupos católicos (e, em algumas regiões, também protestantes) inspirados remotamente na insurgência nacionalista e joaquimita 
do padre Ibiapina, de que o padre Cícero foi continuador, do mesmo modo que antes deste o fora Antônio Conselheiro, a figura mítica da guerra de Canudos.

Para mim, essas referências são essenciais para compreender as personagens e as circunstâncias das fotos dos cinco autores expostos, para decifrar muitas das ocultações e revelações dessas fotografias e para situar social e historicamente a fé popular e a religiosidade que dela decorre. Eu mesmo fiz pesquisas e fotografias nesses diferentes lugares ou momentos de devoção popular - Pirapora do Bom Jesus (São Paulo), São Francisco do Canindé (Ceará), Juazeiro do Norte (Ceará), Monte Santo (Bahia), Círio de Nazaré (Belém do Pará), Aparecida do Norte (São Paulo), Trindade (Goiás), Santa Cruz dos Enforcados (São Paulo) e as regiões de Canudos e Contestado. Quem chega a alguns desses lugares para o pagamento de promessas, é importante reconhecer, não deixa para trás a história da qual a romaria aos lugares santos é apenas momento. Os devotos reavivam e dão visibilidade ritual, reproduzem e recomeçam, as dimensões históricas e simbólicas profundas da realidade social da qual são agentes ativos.

O instante da fotografia não recobre senão um fragmento da temporalidade dessa peregrinação pela vida, dessa busca incessante e inacabável. Por isso, fotografias como as dessa exposição pedem uma demora na sua "leitura" e na sua apreciação. Quase um meditar junto com cada fotógrafo, quase uma liturgia de conciliação do ato fotográfico com o ato interpretativo. Os muitos detalhes secundários de cada foto contêm informações relativas ao âmbito mais amplo e ao tempo mais amplo da realidade dos peregrinos. É aí que o tempo único da fotografia encontra sua contradição. Detalhes que são o âmbito e o tempo dos embates pelo Bem e tudo que ele significa - vida, saúde, justiça, fartura, abrigo. O flagrante de um instantâneo fotográfico pode ocultar muita coisa, pode reduzir a realidade social à brevidade de um fragmento. Mas não pode ocultar e anular as informações da circunstância, do detalhe que contém o seu próprio tempo, o tempo que pode escapar ao olho do fotógrafo.

A estética do detalhe em várias fotos de Tiago Santana sugere, justamente, uma interrogação do fragmentário, no que para mim é um estilo diretamente derivado dos ex-votos de madeira ou de cera. A ida aos lugares sagrados não pode deixar de ser interpretada como breve intervalo, ligeiro descanso devocional numa vida de sofrimentos em busca do mundo da Promessa. Uma romaria purificadora, como fica evidente quando se compreende quem dela participa. $\mathrm{O}$ impacto visual de realidades assim na sensibilidade de um fotógrafo, mesmo que ele disso não saiba "antropologicamente", pode incorporar à composição fotográfica varias evidências de uma história no caminho da Utopia (19).

\section{A imagem fotográfica no imaginário da fé}

A religiosidade popular se apossou rapidamente da fotografia no Brasil. Aparentemente, a fotografia veio aperfeiçoar a função insuficientemente cumprida dos ex-votos no imaginário religioso. O corpo imaginado das toscas esculturas de madeira, mera alusão à parte doente e afetada, contaminada, passa a ser 
substituído pela verossimilhança da fotografia. Das duas uma: ou a verossimilhança já era concebida como representação perfeita do milagre, e os meios disponíveis para expressá-la não estavam disponíveis, sobretudo para os pobres, ou as mudanças culturais do século XIX, que, na sociedade inteira, introduziram a cultura do verossímil, da representação visual "perfeita", criaram a necessidade social de novos recursos visuais para exprimir o imaginário. Já ouvi expressões de admiração em relação a pinturas e desenhos: "Parece fotografia!" Ou reclamações, quanto a fotografias: "Não parece eu", "Não parece ele". Ou elogios: "É eu!"

A construção incorreta das frases é eloqüente e essencial neste caso. Não é raro nas classes populares, no Brasil, a pessoa se referir a si mesma na terceira pessoa, sobretudo na relação com o estranho ou com coisas estranhas às suas tradições. No caso da fotografia, o erro é perfeito. Ao ver-se na foto, a pessoa não se reconhece senão como outro, senão como alteridade, como objeto: "É eu" em vez de "Sou eu".

A parecença é, nessa cultura, tomada como prova de qualidade da imagem fotográfica. Antes da fotografia, num país em que a pintura foi pobre e pouca, os ex-votos pictóricos tiveram grande importância. É significativo que tenham desaparecido quase ao mesmo tempo em que apareceu a fotografia: a imagem do enfermo na cama e num canto do cômodo, como aparição, como proteção invisível, levitando, o santo ou, geralmente, uma invocação de Nossa Senhora vigilante e protetora, a figuração do autor do milagre. Mas a pintura vai aos poucos parecendo, por mais imaginativa que seja, meio insuficiente para testemunhar o milagre. Faz-se necessária a palavra escrita, geralmente extensa, narrando o milagre e sua circunstância. Uma espécie de nota de rodapé da pintura numa cultura em que o imaginário fértil do catolicismo barroco e prolixo pede a complementaridade das expressões no testemunho do acontecido. É verdade que a adoção do uso da fotografia como ex-voto não dispensou a inclusão de textos escritos que explicam o milagre acontecido. Mas, é evidente, também, que a economia de escritos nesse caso sugere a maior eloqüência testemunhal da imagem fotográfica.

Nessa fase, a cultura visual estava profundamente marcada pela consciência de que o real é constituído pelo que se vê e pelo que não se vê ao mesmo tempo, mas que está lá, faz parte do pictórico imaginário. E o que se vê é apenas fragmento do que ocorre. A vida cotidiana estava povoada de seres imaginários, entes benéficos ou maléficos, que disputavam entre si a alma, através do corpo dos viventes. O mundo barroco, na Colônia, é o mundo de batalhas contínuas entre o Bem e o Mal, entre Deus e o Diabo. Numa frase lapidar, posta na boca de um sertanejo, Guimarães Rosa sintetiza: "E Deus mesmo, se vier, que venha armado". A fé é nesse momento a clara expressão da consciência desse combate. É uma fé que transcorre no mundo do imaginário e da imagem mental, de uma imagem que nem sempre tem condições de materializar-se, até por falta de meios técnicos que correspondam apropriadamente ao que está sendo imaginado. 
Mas, a imagem desse imaginário é significativamente confinada ao limite entre a vida e a morte, em face do risco da morte iminente. A necessidade de dar visibilidade ao invisível foi uma necessidade própria do mundo colonial, cujos resquícios persistem de vários modos na cultura brasileira. Era uma necessidade circunscrita a uma idéia de tempo, o tempo da eternidade, do para sempre, do irremediável. O tempo da passagem do perecível para o perene, da incerteza para a certeza. A iminência da morte como momento final de acerto de contas, de pagamento de dívidas materiais e espirituais, de balanço perfeito entre o débito e o crédito, como abundantemente mostram os testamentos da época colonial. E também as figurações coloniais do anjo são Miguel, pesando em sua balança os méritos e deméritos do pecador que bate à porta do Purgatório.

Nesse mundo, a necessidade de imagem e a necessidade de ver muito além do cotidianamente visível são necessidades limitadas à certeza de que o invisível do confronto entre Deus e o Diabo, único momento em que se acercam dos mortais para disputá-los, é um invisível que contém uma potencial visibilidade, a do risco iminente da perdição eterna. Esse risco propõe à consciência do homem comum a necessidade de visibilidade, necessidade de ver, necessidade do conhecimento visual, necessidade da correção possível dos erros da vida nesses momentos liminares de anúncio da morte. A chegada da fotografia ao Brasil, com motivações estrangeiras de uma elite de senhores de escravos culturalmente estrangeira, desconheceu o lugar específico do visual na tradição do país.

Justamente por isso a história da fotografia no Brasil é a história da sua captura por esse momento simbolicamente liminar e pela cultura religiosa que nele tem a sua referência estruturante, a base de sua edificação, que é o medo do invisível e do conflito fatal que ele contém. A fotografia não entra no Brasil pela porta estreita do moderno escasso e limitado. Ela entra justamente pela porta larga da religião e da tradição, do papel fundante que o medo teve na religiosidade engendrada pela Contra-Reforma e pelo Concílio de Trento - mesmo que o elitismo dos difusores da fotografia faça crer que era ela um momento de constituição do moderno no país. Era muito mais, um poderoso episódio adicional da constituição da modernidade, isto é, do hibridismo cultural bifronte e duplamente orientado tanto para o passado quanto para o futuro, tanto para o sagrado quanto para o profano (20).

O advento da fotografia como ícone e como ex-voto sugere uma mudança no imaginário religioso, reflete a redução da fé ao imaginário de um real supostamente sem ocultações, sem invisibilidades, sem demônios. De certo modo, a fotografia vem cumprindo uma função iconoclástica na religiosidade do brasileiro, destruindo o irrealismo fantasioso das imagens e figurações barrocas. A fé da era da fotografia tornou-se outra fé, menos a fé do medo e mais a fé da esperança. Há aí uma lenta transformação que ainda não se cumpriu por inteiro. A fotografia pode cumprir a missão de expressar essa fé, porque o verossímil nega por inteiro as ocultações, desconhece e nega o invisível no real. Também porque se 
difunde entre nós uma fé individualizada, de um crente identificado perante Deus na imagem fotográfica precisa, com rosto, nome e até endereço.

O envelhecimento e a deterioração da imagem fotográfica, na obra de Antonio Saggese, documenta justamente a materialidade da nova e moderna imagem no mundo religioso, uma certa secularização da crença. Mais do que deterioração do ex-voto, uma certa protestantização da crença; contraditória, porém: a imagem ainda é um suporte da fé. Mas uma imagem pobre, empobrecida, desprovida dos enigmas próprios do grande embate pelo gênero humano, entre Satanás e Deus.

A inserção da fotografia no mundo dos ex-votos, porém, nos fala de uma desconfiança em relação ao imaginário de que ela faz parte - urbano, moderno, racional, preciso, verdadeiro. A fé se pratica como desconfiança em relação ao mundo secular e novo. Vai perdendo a sua dimensão barroca, o movimento próprio de corpos que se movem em direção ao céu e à luz divina, se contorcem, sofrem, aprisionados no eixo imobilista do pecado e do terrenal. A fotografia introduz a imobilidade definitiva, secular e material, moderna, dos corpos no imaginário da fé. As pessoas posam tesas, duras, imóveis, reflexo das dificuldades técnicas próprias da origem da fotografia.

Nos santuários, as salas das promessas ou salas dos milagres documentam essa mudança de concepções. Constituem uma espécie de teatro da fé, um lugar para ser visto, um espaço de testemunho através de objetos, de ex-votos. Um modo de fazer o outro enxergar, de fazer ver para fazer crer, que constitui o testemunho por excelência. Quem recebeu a graça torna-se o cúmplice do santo, age como tal alardeando seus poderes. O milagroso silencia sobre seus milagres e seu silêncio é próprio da santidade. Quem recebe o milagre é quem, na sua gratidão, deve falar do acontecido, exibir os detalhes, as evidências, as provas testemunhar.

Há várias formas de testemunhar os milagres operados no corpo. De um lado, os objetos que tiveram contato com o corpo de quem recebeu a graça, como o vestuário (em Aparecida há um verdadeiro guarda-roupa de oficiais das forças armadas e das polícias estaduais que receberam alguma graça da santa): o equipamento de identificação como parte da própria identidade, a identidade oferecida como testemunho do milagre e prova de fé.

De outro, os objetos que fizeram parte do corpo, especialmente os cabelos ou mesmo as próteses. Numa foto de Saggese, os pedaços de barba que fazem a moldura de um rosto barbado que recebeu a bênção de um milagre constituem uma óbvia desordem na concepção profana do corpo e do visual [Fото 1]. E o mesmo se pode dizer da foto deteriorada de uma jovem cujo rosto tem como moldura seus próprios cabelos longos e louros (21).

Esse velho meio de afirmação da fé, como deixar crescer os cabelos para doá-los a uma santa como peruca, é forte costume colonial, sobretudo entre mulheres: uma troca de partes do corpo, entre o corpo profano e mortal e o 
corpo sagrado e imortal. O milagre é um momento de promiscuidade entre o sagrado e o profano, e resulta na sacralização parcial do corpo, na captura do sagrado pelo profano, que é ao mesmo tempo o seu contrário. Há um certo reconhecimento de que a parte do corpo que foi objeto do milagre por meio dele se sacraliza. As partes sagradas do corpo, como o útero e o seio, nas mulheres; os olhos, em todos. Os momentos sagrados no corpo, na infância, na gravidez. É significativo que não haja ex-votos das partes pudendas, das partes sexuais do corpo, o profano e o pecaminoso por excelência, a negação da sacralidade, o instrumento do prazer e do pecado.

A fotografia ex-voto anuncia justamente a desordem que há na relação entre profano e sagrado, entre mortalidade e imortalidade, na oferenda sacrificial de uma parte do corpo, no sacrifício da privação de um ornamento natural.

A figuração das partes do corpo que foram objeto da intervenção divina refere-se a uma espécie de segundo nascimento, de ressurreição parcial. A representação por excelência. O estar em lugar de. É aí que mais intensamente se revela o imaginário, não só através do imaginado, mas sobretudo do fazer o outro imaginar.

O milagre nos fala do limiar da morte, a desordem suprema porque definitiva, porque reordena os mundos - o do transcendente e o da vida. O milagre nos fala do tempo, nos fala de transubstanciação das partes mortas, doentes, do corpo em partes vivas, sadias; nos fala de renascimento, de transformações.

A ordem da exposição de fotos e objetos nas salas dos milagres nos fala, porém, de classificação e nos fala de espaço, de permanência, de poder. Portanto, as salas de milagres dos santuários brasileiros não nos falam apenas de imagens fotográficas, que beatas e funcionários do sagrado procuram ordenar para assegurar a sua mais intensa visualização, como se vê na foto que Antonio Saggese fez na sala dos milagres de Aparecida do Norte, em 1992 [ғото 2]. O ângulo escolhido ressalta, justamente, a pequenez de quem observa a sala, o testemunho coletivo constituído por milhares de fotografias de pessoas alcançadas pela graça de um milagre - uma espécie de abóbada da fé. Tiago Santana, aliás, deu-se conta desse detalhe significativo ao construir, no recinto da exposição Benditos, em São Paulo, uma capela imaginária ao redor da imagem do padre Cícero, cujas paredes e teto são forrados por fotografias de pessoas.

Mas a ordem do exposto não é a ordem do acontecido nem a ordem do testemunhado. A ordem do exposto, o exótico dos critérios de classificação, apenas revela a tentativa burocrática de assegurar a ordem num espaço de poder, que é o espaço do templo e dos gestores do sagrado. Aí se propõe a contradição que há entre o sagrado e o profano. É verdade que o sagrado regenera as rupturas do profano, repõe a aparência da ordem na desordem do inaparente, do que não pode ser visto. Pode apenas ser testemunhado. Porém, há uma grande contradição entre a visualidade proposta pelo beneficiário do milagre e a visualidade exibicionista e classificatória que os funcionários do sagrado procuram dar aos objetos de que são apenas depositários e gestores. 
Assim como os funcionários do sagrado procuram ordenar visualmente os objetos que testemunham a eficácia da fé, cabe perguntar que ordenamento propõem os fotógrafos dos atos de fé. Qual é propriamente o milagre da fotografia? Em Saggese, esse intuito ordenador é claro: ele intenta mostrar e demonstrar a materialidade obsolescente dos ex-votos, a mortalidade dos testemunhos da imortalidade, as imagens fotográficas. Só pode fazê-lo proclamando a imortalidade estética da fotografia, o estilo, a fotografia como obra de arte. A fotografia da fotografia que ele pratica procura restituir à fotografia a sua dimensão de arte. Isto é, procura resgatá-la da promíscua convivência com o imaginário vulgar e o senso comum. Procura reencontrar no produto banalizado como ex-voto perecível, ordenável pelos gestores do sagrado, a desordem do único, a sacralidade do estético, a universalidade de um modo de ver, mais do que simplesmente do que é visto.

\section{Desencantamento e desconstrução nas imagens da fé}

Essa perspectiva reaparece em Christian Cravo de um outro modo. Ele intui a sobrevivência dos resquícios do barroco numa realidade social aparentemente desprovida de estilo, a dos pobres, dos penitentes, dos que têm fé. É eloqüente a foto do penitente, em Bom Jesus da Lapa, que carrega um crucifixo, em que as pessoas que o circundam são quase tocadas pela mão estendida de um santo barroco, um missionário agônico nas contorções do êxtase [Fото 3]. Ela constitui uma inigualável expressão dessa busca, dessa procura de liames com o mundo do atual, do sem-estilo. Cravo documenta a persistência de um mundo em que o estilo era fundamental, em que a vida cotidiana ainda não se constituíra, a vida de todo dia mergulhada integralmente no sagrado, como foi o mundo colonial. Um mundo que sobrevive de muitos modos nessa força do sagrado, nas invasões constantes de um cotidiano indeciso e mal constituído, inacabado e inacabável.

Só a fotografia permite esse encontro dos tempos, essa durabilidade estética da fé no mundo residual da Conquista, mesmo na suposição discutível de que a fotografia congela o tempo e institui o seu tempo, que é apenas o tempo do aparente. A imagem barroca, que foi por séculos a mediação na construção social do catolicismo popular, se encontra na mesma cena com o homem comum possuído pela mesma fé barroca. $\mathrm{O}$ ato de fé move e comove os circunstantes, pessoas e imagens. $\mathrm{O}$ crente que ergue o crucifixo enche de vida o Cristo agonizante que segura com as duas mãos como se fosse um Cristo ressuscitado, ressurgindo das sombras da morte, como se fosse um milagre triunfal do povo da rua. Há movimento e vida nessa imagem que mescla estilos de um quadro da Renascença com o do Cinema Novo brasileiro, como O Pagador de Promessas, de Anselmo Duarte, ou Deus e o Diabo na Terra no Sol, de Glauber Rocha.

Não obstante, um certo ceticismo se apresenta nas fotografias de Tiago Santana, em Juazeiro do Norte, uma certa descrença presente no registro de decodificadores do que está sendo fotografado - decodificadores que dessacralizam a cena, que num certo sentido a poluem. São referentes que impedem a invasão 
da fotografia por ficções de sacralidade pura e exemplar, por algo que poderia ser definido como fotografia edificante. É uma atitude propriamente fotográfica e, num certo sentido, herética. Ainda que com outra linguagem, expressa valores parecidos com os que orientam a fotografia de Antonio Saggese. Isso talvez se explique pelo fato de que, sendo nativo da região, Tiago Santana cresceu presenciando a mescla visual, a indistinção de sagrado e profano, a banalidade do aparente na rotina de uma cidade de peregrinação e de encenação de episódios de fé extrema. Justamente aí a fotografia fala mais do fotógrafo do que do fotografado.

O que pode um fotógrafo ver no barroco tardio e insistente de tantas manifestações de misticismo e fé das festas religiosas brasileiras e dos lugares de romaria, lugares de acerto de contas com o sagrado?

No seu olhar de surpresa e de estranhamento, pode ver e fixar aspectos miúdos de um grande e solene rito de reconciliação do homem com sua divindade perdida. Porque o humano aparece inteiramente na coisa adorada. A fé popular é em grande parte o reconhecimento penitencial desse estranhamento, a relação culpada e penitente com a divinização das carências que se consubstanciam na divindade imaginada, buscada, desejada.

Os fotógrafos da exposição Acts of Faith, cujas obras estão expostas, documentam, no detalhe miúdo de gestos dirigidos ao sagrado e nos intervalos estranhos que o sagrado permeia, justamente as evidências do sagrado, a construção social do sagrado. A participação litúrgica do romeiro, do pagador de promessas, dirige liturgicamente a atenção dos participantes para o sagrado em si. O participante da liturgia não tem com o sagrado a relação de observador. Ele é parte, com sua presença, da própria sacralização, porque ali ele se consagra.

O olhar de certo modo herético ou descrente do fotógrafo vê o invisível, isto é, o irrelevante do ponto de vista litúrgico, os referenciais de desconstrução da sacralidade da imagem fotográfica (22). Sacralidade, aliás, que capturou a fotografia como ex-voto muito antes de a fotografia se interessar pelo sagrado. $\mathrm{O}$ fotógrafo estranha o que vê. A fotografia é aí, portanto, o documento desse estranhamento revelador. Os temas falam das miúdas e, aparentemente, irrelevantes características da relação com o sagrado. Falam, pois, de um sagrado que não está apenas, nem essencialmente, na liturgia e, portanto, nas ações dos funcionários do sagrado, mas de um sagrado que está em toda parte, embora não necessariamente em todos os momentos. Um sagrado, porém, que domina um tempo maior da vida do que apenas o tempo do ofício litúrgico.

O fotógrafo, portanto, desmente sem querer a tese da fotografia como congelamento do tempo, do mesmo modo que essa falsa premissa é desmentida pela própria existência de uma disciplina como a sociologia visual. A indagação sociológica sobre o visual é impossível a partir do pressuposto de que na fotografia o tempo é congelado, fixado, suprimido. Pois a sociologia lida com processos sociais e, portanto, com a mediação de alguma concepção de tempo, seja o tempo da interação social, seja o tempo da História. 
Esse é, também, um sagrado que se apossa mais intensamente do corpo do que do espaço que o circunda, de modo que as fotografias nos revelam mais os gestos da prestação ritual e do corpo como mediação entre o sagrado e o profano. Os corpos revelados na sua singularidade pelo cenário que ora confirma o sagrado, ora o nega. Tudo depende do olhar do fotógrafo em face da polissemia visual densa dos cenários em que se desenrolam os atos de fé.

Por isso, Antonio Saggese pode propor a deterioração da imagem fotográfica dos pagadores de promessa e seu envelhecimento, sua promiscuidade e sua desordem como desconstrutores do sagrado. Na verdade, esse não é o foco primeiro que explica sua fotografia. Em suas fotos de fotografias em túmulos deteriorados de diferentes lugares (23), de pôsteres eróticos consumidos pela sujeira de borracharias, de marcenarias, de oficinas de conserto de automóveis, ele propõe o reconhecimento do que se poderia definir como o desencantamento visual da fotografia. Mas, justamente, essa proposta ganha desdobramentos nas fotografias de ex-votos. Esse paradigma de deciframento da fotografia destinada ao consumo, mais do que ao uso, tem um alcance adicional quando o autor dirige suas lentes para o terreno das práticas religiosas. Aí se amplia o âmbito de conjecturas relativas a um certo fetichismo da fotografia, que é o objetivo de seus ensaios: por que a foto deteriorada, convertida em objeto de consumo, que seria destinada ao lixo, permanece como ícone, venerada ou admirada em paredes de adobe, em meio a ferramentas ou recoberta de serragem em marcenarias e carpintarias?

Em um de seus trabalhos, Saggese fotografa duas fotografias comparativas e comprobatórias do milagre no homem que exibe o braço direito enfermo e, na seqüência, o braço direito são. Coincidindo com partes do corpo fotografado, cupins cor de ferrugem se aglomeram sobre a imagem em preto e branco [नото 4]. Uma terrível proposição visual das térmitas devorando a fotografia, uma metáfora do corpo do fotografado sendo devorado pelos vermes. Justamente, a afirmação da ressurreição da parte doente do corpo. Uma alegoria da morte e da fé que pode vencê-la.

A imagem, a fotografia e o ex-voto propõem-se como expressões mortas e mortais da celebração do milagre e da vida que o milagre assegurou. Nesse envelhecimento, a fotografia fotografada se revela fotografia, fetiche, como quer Saggese. As composições falam de contextualizações distantes dos vívidos e solenes momentos de pagar promessa. Saggese nos fala de uma fé esmaecida pelo tempo, devorada pelo suceder dos dias - imagens desfiguradas pela mescla insólita que junta solenes esculturas e pinturas com prosaicos objetos do mundo simples dos que têm fé. Fala, também, do confronto inevitavelmente corrosivo da imagem religiosa com a imagem fotográfica dos que têm religião, como se vê na foto feita em Congonhas do Campo: a parte inferior de um quadro que retrata o Crucificado com dezenas de fotos encaixadas a esmo entre a tela e a moldura, antiga e dourada [Fото 5]. De verdade, Saggese nos fala da pobreza cotidiana da fotografia que se deixa consumir pelo tempo muito depressa. Nela o contem- 
porâneo se torna obsoleto - o produto fotográfico não resiste à corrosão que lhe impõe a obra de arte e o sagrado. Saggese nos fala da fotografia como banalização da imagem desprovida de dimensão estética.

A fotografia deteriorada, usada mais do que contemplada, ganha consistência e dimensão estética na fotografia da fotografia, na crítica estética do ato fotográfico que se reduz ao produto de uma fé capturada pela coisa. Saggese propõe uma fotografia cuja pompa está na circunstância.

A obra de Saggese, ao mostrar a fotografia abandonada nas salas de milagres dos santuários, pode nos dizer, também, que a vida da fotografia só pode existir no interior de processos interativos, isto é, no calor da memória. A fotografia como instrumento da interação imaginária com os ausentes (e com os mortos). Os panteões fotográficos nas casas de família, nas paredes, nos álbuns, nas gavetas, nas caixas de sapatos, nos falam de uma hierarquia da memória, dos próximos e dos distantes, desde os que precisam ser revistos imaginariamente com freqüência ao longo dos momentos da vida cotidiana, todos os dias, aos que precisam ser vistos na liturgia familiar do lembrar, nos episódicos momentos de visitar os álbuns de família, até os que são acidentalmente revistos nas buscas em caixas e gavetas.

Ao fotografar as fotografias mortas e abandonadas dos panteões sagrados das igrejas, Saggese nos envia diretamente ao cenário próprio da fotografia, como documento da imortalização que há nos afetos, no amor, na memória. Sociologicamente, esse tipo de fotografia nos fala da dimensão imaginária dos processos interativos e, portanto, das circunstâncias muito específicas da morte social, como morte da lembrança, como falecimento da memória. A fotografia se constitui num meio essencial de sustentação da sobrevida dos mortos, da continuidade imaginária das relações sociais mesmo depois da morte (24). Por esse meio, falanos da comunidade imaginária que se sobrepõe à mortalidade física do contemporâneo.

É dos vivos que a fotografia quer falar, mesmo quando fala de mortes culturais e simbólicas. Ou quando nos fala de um sagrado cercado, ameaçado de corrosões de todo tipo, mas que, no entanto, persiste, se renova, até mesmo incorporando a fotografia que o condena.

Nas fotos de Bassit, o sagrado se implanta num código de vivos e vivacidades. Aquele pequeno Cristo crucificado no meio da multidão de devotos em Bom Jesus da Lapa é mais um companheiro do que um deus [Fото 6], do mesmo modo que os ex-votos de Canindé, amontoados, mistura desordenada de cabeças, pés, braços, desindividualizam promessas e milagres [ғото 7]. Mas é sobretudo o casal idoso de Canindé, a mulher com a maqueta de uma casa na cabeça [नото 8], que parece oferecer-se ao fotógrafo como prova visual do caráter profano das reivindicações dos penitentes. Talvez.

A casa simbólica é modesta, com o número e uma cruz desproporcional na fachada. Quase um pedido de bênção com endereço para que não haja erro. 
Romeiros e penitentes carregando maquetas de casas na cabeça podem ser vistos em vários centros de devoção no Brasil. Vi um grande número de pessoas carregando essas maquetas na procissão do Círio de Nazaré, em Belém, em 2000. Muitas dessas casas tinham detalhes, o que parece indicar a representação da casa real, até com garagem para o carro.

Neste caso, em particular, a casa é pobre e simples. É a cruz na fachada que nos fala da dimensão simbólica da casa na cultura sertaneja, velho costume medieval que chegou ao Brasil e à sacralidade da casa já no início da colônia - uma casa uterina, como demonstram os ritos funerários e os cuidados e tabus com os mortos na ordem da disposição do corpo e da saída do funeral: ordem inversa à do nascimento (25). A cruz pintada na porta da frente, é um sinal para repelir e afastar o anti-Cristo. A casa, como casa de Deus, aparece nas folias do Divino e nas folias de Reis já no intróito dos cânticos, associando o sacrário da hóstia com a casa da família: "Deus te salve, casa santa", entoam os foliões cantores.

Mas é uma casa que é fruto de trabalho. No interior do Brasil, a mulher normalmente faz seu trabalho de carregar produtos da roça em cestos assentados sobre uma rodilha de pano na cabeça - potes de água, trouxas de roupa, feixes de lenha. Um gesto bem feminino de trabalho numa cultura em que não raro a mulher se considera "burro de carga". Aliás, a palavra rodilha significa também pessoa desprezível, subalterna, insignificante. Assim, a casa, na cultura sertaneja, é uterina na arquitetura simbólica e também feminina nas funções. É a mulher quem paga a promessa. O homem é aí mero coadjuvante, como acontece no geral na vida doméstica rural. A casa, com seus utensílios, é da mulher. Daí os ritos de purificação que a cercam, as providências para evitar sua contaminação pela morte e pelos malefícios que sempre lhe são externos e, especialmente, os cuidados para afastar o mau-olhado em relação aos recém-nascidos. Na cultura sertaneja e da religiosidade popular, a casa está simbolicamente oposta à morte e ao morto e a tudo que possa matar, física e simbolicamente.

Embora seja pouco provável que o fotógrafo tenha clareza a respeito dessa dimensão antropológica do que está fotografando, justamente este fato acentua a importância documental de sua fotografia. O que pode ter sido pictoricamente interessante no ato de fotografar é interessante justamente porque carrega consigo uma completa e evidente carga de significados. Embora os fotografados não narrem expressamente o conteúdo antropológico de sua representação, de sua teatralidade, seus atos, vivências e representações compõem deliberadamente um fato social total. As expressões e a ornamentação litúrgica do ato dizem tudo, conectam o gesto ao objeto, definem o todo do pagamento de uma promessa ou de realização de uma promessa. Mais, a idade dos fotografados nos fala da casa como projeto de uma vida. O sentido de uma vida inteira está ali - a casa e a família.

Vejo esse contraponto dessacralizador também em Procissão, de José Bassit, feita em Juazeiro do Norte [ғото 9]: a casa rústica de pau-a-pique ou adobe, as janelas abertas, o morador debruçado numa delas, apreciando a procissão que 
passa, cuja sombra se projeta sobre as paredes da casa, a cruz, os estandartes. Não obstante, os homens estão de chapéu.

Algumas perguntas: Por que as janelas estão abertas? Por que o morador está em casa e não na procissão? Por que alguns homens na procissão estão de chapéu? A própria fotografia não oferece respostas a essas perguntas. Não há nada nela que ofereça um decodificador. As janelas abertas indicam, sem dúvida, uma orientação oposta à orientação da morte, ocasião em que as janelas são fechadas. As janelas abertas falam do sentido profundo da procissão de peregrinos, a sua força sacralizadora. Falam de acolhimento à bênção e à vida que ela representa. A janela aberta é um convite a que o público invada o íntimo, a que o que é bendito se aposse do que é sagrado, a casa, o lugar da família e da vida.

Em Juazeiro do Norte, um morador que não participa de uma atividade tão importante como a procissão pode indicar várias coisas: uma delas (que aparece, de certo modo, na fotografia de Santana) é a cidade de romeiros como cidade voltada para o de fora e não para o de dentro - o de dentro numa relação de aparente indiferença quanto ao sagrado, alguém cuja rotina de vida não é demarcada pela contraposição de festa e trabalho, de sagrado e profano. A rotinização do sagrado gera a passividade do morador, cuja vida é quase certamente dependente de atividades econômicas relacionadas com a vida religiosa do lugar. Ele é quase um funcionário do sagrado, um auxiliar do culto.

Essa procissão de sombras e fantasmas pretende ser, também, a mensagem do fotógrafo. Entre as sombras que desfilam e as pessoas que dela participam, o fotógrafo viu sentido nas sombras e não nas pessoas. Viu sentido na alegoria da fé e não na sua prática, não no ato de fé. Ou, então, quis atribuir uma dimensão alegórica a esse ato. Há nisso um ver fotográfico que não é cotidiano, que se preserva em relação àquilo que contempla, que não se deixa convencer pela tentação do documental.

Cotidiano é o ver do morador da casa, que se debruça na janela como mero espectador no momento da procissão e da fotografia. Ele é real e não alegórico. Ele vê os que crêem. Ele contempla o teatro da fé, a celebração da fé. O cotidiano contempla o não-cotidiano. Nessa foto, o fotógrafo celebra seu próprio estranhamento. Nela também o cotidiano contempla o não-cotidiano da fé transformada em festa e teatro religioso, em agir não regulado por regras cotidianas, as regras da sobrevivência. O tema do contemplativo e o fotógrafo contemplativo, como na fotografia de Saggese, dão consistência justamente àquilo que nega a dessacralização.

Os chapéus na cabeça intrigam. Numa população sertaneja, que, ao mencionar o nome de Deus e de qualquer santo, costuma levantar o chapéu em sinal de respeito, esse estar de chapéu na procissão nos diz que a sacralidade da procissão não é completa, nos diz que a procissão é momento de ir ao sagrado, mas não é o sagrado. É o preâmbulo do sacro. Isso talvez explique a passividade espectadora do homem na janela, a desnecessidade de incorporar-se à sacralidade provisória do momento. 


\section{A fotografia e o fotógrafo na construção social do sagrado}

Nessas contraposições, quero destacar em particular a foto em que Bassit retrata o romeiro ciclista carregando pesada imagem do padre Cícero na cabeça, enquanto ao lado passa um caminhão de romeiros, um pau-de-arara [Fото 10]. Essa foto pode ser tomada como uma combinação de preciosismo técnico e grande sorte do fotógrafo. Mas é sobretudo um documento sobre a competência de Bassit. Na composição da foto tudo se ajusta, até mesmo a sombra do ciclista e seu santo na porta da cabina do caminhão de romeiros, como um contraponto da devoção apressada e descansada. Em primeiro lugar, documenta uma certa hierarquização da fé dos romeiros. Há romeiros e romeiros. Há os que vão ao lugar sagrado, como os que estão no caminhão. O ato de fé se cumprirá sobretudo no lugar de destino. A sacralidade do ato fica confinada ao momento específico de testemunhar a gratidão. Tiago Santana também fotografou situações que testemunham essa concepção de fé: a do romeiro cujos gestos e modos falam de uma fé fragmentária, uma fé já atravessada pelo cotidiano e pelo moderno. Santana sublinha os momentos, documenta essa modalidade de fé residual de uma história que sucumbiu a transformações e desfigurações.

O ciclista de Bassit cumpre desde a partida, e ao longo do caminho, um ato penitencial. Sua fé é íntegra, integral. Não está confinada aos momentos de uma liturgia fragmentada, seqüencial, na qual o leigo é mero acólito do celebrante e mero cliente da instituição religiosa. O ciclista da foto cumpre funções sacerdotais claras. Há uma dimensão sacrificial no seu gesto e na sua opção. Ele sabe o grave que seria se a imagem do padre Cícero caísse e quebrasse, uma profanação. Ele oferece a Deus mais do que a viagem ao lugar sagrado. Ele oferece sua fé, a certeza de que o poder do Padim Ciço não deixará que isso aconteça. Na verdadeira fé não há riscos, apenas certezas absolutas. Sobre a bicicleta trafega um corpo sacralizado pela fé e pelo sacrifício de semelhante mandato. Ela é o andor do santo, o pedestal. Faz-nos lembrar das práticas penitenciais dos que carregam pesadas pedras na cabeça para pagar suas promessas. Um são Cristóvão do sertão, que carrega nos ombros o profeta em sua travessia. Uma forte concepção da fé barroca: só há fé no sofrimento e sofrimento ostensivo. Uma fé testemunhal, missionária, destinada a comover e converter os incréus. Uma fé ainda colonial.

Essa foto nos fala da sacralização do corpo no correr do ato penitencial, tema que, de vários modos, aparece na obra de outros fotógrafos expostos. Nas fotos de Christian Cravo está proposta a função litúrgica das mãos enquanto liame entre o mundo carnal e o mundo espiritual: junto ao esquife do Senhor Morto dos índios kiriri, de Mirandela [Fото 11], na casa dos milagres e na prece de uma mulher na igreja de Juazeiro do Norte [Fото 12]. Ou na tentativa inútil de tocar o rosto torturado do Senhor dos Passos, em São Francisco do Canindé [Fото 13]. Ou ainda nas mãos erguidas para o céu, em Bom Jesus da Lapa [Fото 14]. As mãos, em particular a mão direita, estendem-se para colher e recolher a sacralidade dos santos ou dos céus. É extrema a importância das mãos, em espe- 
cial da mão direita, no contato com o sagrado - mãos de um corpo dividido, decomposto em partes, classificado, inserido no universo das dilacerações do mundo: o sagrado e o profano, o puro e o impuro, a mão direita e a mão esquerda.

O poder simbólico das mãos reaparece na obra fotográfica de Tiago Santana sobre Juazeiro. Não é qualquer mão que enlaça o carnal e o espiritual. As mãos nas fotos de Santana são no geral mãos profanas no cenário do sagrado e não as mãos da sacralidade. São mãos da vaidade ou mãos utilitárias ou mãos inúteis. Em sua fotografia, elas são o punctum: o que uma mão diz, a outra desdiz (26) [Fото 15]. Essa desconstrução está claramente presente na foto feita em Juazeiro do Norte, em 1993, das duas mulheres rezando com a cabeça encostada na pedra, ao pé da escultura monumental do padre Cícero. A mão esquerda da mulher mais nova, de trança e roupa escura, constitui um quase sacrilégio no ambiente de beatas e romeiros de Juazeiro do Norte. Pelo teste que fiz na foto preto-ebranco, as unhas estão pintadas, provavelmente de vermelho, uma cor que causa arrepios nos seguidores do padre Cícero, evitada em trajes e objetos. Os romeiros usam de preferência o azul claro e o branco, cores de Nossa Senhora das Dores, da devoção do Padim (27). A mesma mão, é verdade, segura um terço, mas também ostenta anéis e uma pulseira. A pessoa ostenta no pescoço um colar de metal, provavelmente dourado. O contraste é claro com a senhora idosa, ao lado, de roupa clara, sem adornos, que pousa a testa sobre a mão direita. As mãos estão aí polarizadas no seu simbolismo forte na religiosidade popular brasileira: do mal é a mão esquerda e do bem a direita. Opostos que se repelem, aqui marcados justamente pela mão esquerda, que ostenta o ouro, o bem da Besta, como advertem os textos de cordel sobre as profecias do padre Cícero, textos tão cheios de sugestões de imagens. A mão profanadora que contrasta com a cena reaparece na foto de 1995, dos fiéis na via-crúcis da penosa subida ao horto. No canto esquerdo, a pessoa negra olha na direção contrária enquanto consome um picolé [Fото 16].

De diferentes modos, os temas desconstrutivos estão presentes nas fotografias dos cinco autores.

Adenor Gondim documenta momentos solenes dos desempenhos rituais da Irmandade de Nossa Senhora da Boa Morte, de Cachoeira, na Bahia. Essa corporação de mulheres descendentes de escravos africanos, que praticam o candomblé, inverte o costumeiro sincretismo, que apresenta em primeiro plano santos católicos que são, ao mesmo tempo, ocultações de divindades africanas. Em suas práticas religiosas, essas mulheres proclamam a mortalidade de Nossa Senhora que, segundo a crença, não morreu, mas foi arrebatada. Humanizam, portanto, a mãe do Deus católico e a tornam sua cativa, velando-a como se morta fosse no dia da celebração de sua ascensão ao céu [Fото 17]. Praticam algo que é, certamente, o elemento constitutivo mais forte do catolicismo popular: as inversões, o manejo dos contrários como meio de lidar com a conciliação cultural impossível, a funcionalidade irrealizável. 
Em Canudos e no Contestado, guerras camponesas de motivação religiosa, as inversões reencantaram o mundo, regeneraram as conexões rompidas e as estruturas sociais dilaceradas pelas inconsistências do mundo material e profano. As devotas da Boa Morte atuam no limiar do profano e do sagrado, mas também no limiar do catolicismo e do candomblé. A bela e competente fotografia de Adenor Gondim mostra-o bem. Negam, de fato, o suposto sincretismo. Apossam-se dos paramentos católicos, como a estola da sua celebrante, enquanto adorno adicional de suas vestes solenes, rituais e tradicionais.

Um dos aspectos sociologicamente mais importantes da existência e atuação da Irmandade da Boa Morte está na substancialização das palavras. Nossa Senhora da Boa Morte, na crença católica, não é a Madona que morre, mas a que faz companhia ao moribundo, que abre seu caminho no doloroso transe, na agonia. A designação de sua devoção, no entanto, foi lida ao pé da letra: uma Nossa Senhora que tem uma boa morte, a morte desejada, cercada pela família vicária, as negras egressas do cativeiro, que, com ritos, orações e a luz das velas, asseguram-lhe a libertação que a boa morte representa. No seu contrário, ela se torna uma Nossa Senhora que morre, que inverte os códigos e os poderes de que é expressão e símbolo. Uma Nossa Senhora mortal que carece do amparo dos humanos e, dentre eles, dos mais humilhados, os que carregam no corpo e na história pessoal as marcas profundas do cativeiro injusto, para que se efetive a dialética da ressurreição.

Essas desconstruções e inversões enchem de imagens e adornos os rituais. E, também, de imagens possíveis, como as imagens fotográficas, que vemos aqui.

As religiões populares no Brasil têm sido intensamente visuais. Excetuados episódios de repressão policial contra as culturas africanas (o candomblé, a capoeira), em que as práticas tiveram que se disfarçar no interior de outras formas culturais sancionadas pela lei ou pela tradição, desde a Conquista as práticas religiosas sempre tiveram intensa visualidade. E o visual parece ter estado associado não só à teatralidade da relação com os catecúmenos: a colonização foi também colonização visual, colonização do olhar dos povos subjugados.

É possível fazer uma ampla etnografia do olho, do olhar e do visual na cultura subalterna das populações rústicas do Brasil. Essencial é a centralidade simbólica do olho na agonia, no momento da morte, juntamente com a importância do ouvido e da fala (da boca). O crucifixo ou o santo de devoção do moribundo é para ser visto, tocado e beijado no momento extremo, um modo de ocupar os sentidos no instante do perigo maior, o risco da posse da alma pelo demônio - um circunstante obrigatório no imaginário da agonia no catolicismo popular brasileiro. Esse é o momento supremo do visível, justamente quando o visível se nega no invisível das ocultações próprias desse momento liminar. Negase no que tem visibilidade unicamente através da fé.

Aí se constitui o campo socialmente ambíguo e contraditório em que está situada a rica diversidade de imagens possíveis em que os fotógrafos podem mo- 
ver-se. Esse é um mundo de tradição, mas também de criatividades potenciais, de interveniências possíveis, de expressões formalmente novas do que parece antigo e persistente.

Se em Cravo e Gondim existe uma estética da fé, uma recaptura do Barroco que ainda há nas evidências da fé por parte dos crentes, em Bassit, Santana e Saggese existe um intuito claro de negar esse Barroco, de indicar a materialidade circunstante da prática da fé no catolicismo popular. Os dois últimos nos falam do progresso inevitável do que é propriamente secular, do cerco que limita e demarca até os momentos mais solenes e de maior entrega na manifestação da fé, como o das romeiras rezando de cabeça encostada na base da estátua monumental do padre Cícero.

Pode-se, pois, refletir não só sobre a fotografia dos fenômenos religiosos, mas também sobre as circunstâncias específicas da absorção do fotógrafo na própria construção social do sagrado.

Nos vários centros religiosos ou lugares de peregrinação em que estive, é possível observar uma gradação no comportamento dos fotografados. Impõe-se ainda a proposição de que não só a fotografia se incorpora ao sagrado, mas também o fotógrafo. Admiti-lo na cena sagrada, tolerar sua atuação diversa da atuação propriamente litúrgica, é tolerar sua intrusão e recriá-lo simbolicamente como protagonista do culto, mesmo que disso ele não se dê conta.

Nesse caso, contraditoriamente, o fazedor de imagens é reconhecido como um iconoclasta potencial. Sua iconoclastia está no desconstrutivismo de suas composições, no seu necessário afã de superar e negar o realismo da verossimilhança. Está na sua missão de ir além da suposta epistemologia do olho e do olhar. É nesse plano que a fotografia pode tornar-se obra de arte. É nesse plano, também, que ela pode se tornar antropológica e sociologicamente documental (28), o que me permite supor que o tempo e o espaço do sagrado nessa cultura de conversão, que é a do catolicismo popular, constituem-se em mediações ao mesmo tempo demonizadoras e includentes. É nesse maniqueísmo autoprotetivo que se move (ou não se move) o fotógrafo dos fenômenos religiosos e é nele que a fotografia pode ter (ou não ter) abrigo e sentido.

Nos momentos mais sagrados, há maior indiferença em relação a quem fotografa. São os momentos de maior concentração e compenetração. Momentos em que as pessoas se deixam confundir com o sagrado: elas próprias são componentes da sacralidade. Há uma certa metamorfose das pessoas, uma despersonalização, uma queda da máscara, da persona. São os momentos de intensa objetivação do sagrado, de constituição de um todo único, singular, específico na comunhão do sujeito e do objeto. Um momento de transfiguração.

Pude ver isso em certos momentos no Círio de Nazaré. Momentos de intensa emoção, de intensa identificação com o objeto sagrado, de intensa entrega. Em Aparecida do Norte, na sala das velas, também é possível ver isso, ainda que com menos dramaticidade. A atitude é mais atitude de oração, de contem- 
plação. Em Bom Jesus de Pirapora, o mesmo pode ser dito das pessoas que sobem a escada para orar brevemente aos pés do Cristo sofredor. E aí, como no Círio, também se vê a necessidade de tocar o objeto sagrado, o toque que assegura a consumação do sagrado e a purificação do crente. As fotos que fiz dos puxadores da corda da berlinda de Nossa Senhora de Nazaré, na procissão do Círio, são fotos de corpos e, sobretudo, rostos torturados pela dor e pelo sofrimento físico. (Uma procissão que teve 1,7 milhão participantes no ano 2000.) $\mathrm{O}$ espaço circundante se sacraliza nessas atitudes, incorporando todos e tudo, ainda que com diferenciações óbvias, do mais sagrado ao menos sagrado. Há uma ordem que inclui tudo nas gradações do sagrado.

Nos lugares de romaria, é comum a realização de uma foto de família defronte a uma imagem do santo ou, sobretudo, defronte à fachada da igreja. Até hoje os romeiros que vão a Aparecida do Norte querem ser fotografados diante do santuário antigo, quase contemporâneo da aparição da santa, mesmo que seja para depois levar as fotos para a sala de milagres no monumental e moderno santuário relativamente distante. O novo santuário é o lugar da missa e o velho santuário ainda é o lugar do apogeu da fé. No novo santuário estão os padres e no velho está a santa, não a imagem - a santa imaginada. A fotografia entra nessa fé produzindo a necessidade de imaginar o invisível, que é o sagrado, simbolizado pelo templo antigo. Daí a importância que adquire a figuração do sagrado nas fotografias de recordação de peregrinações e romarias.

Nesse sentido, o aparecimento da fotografia nesse universo da fé veio preencher uma necessidade: a necessidade de imaginar o sagrado, de imaginar-se no sagrado, e a necessidade de verossimilhança nesse imaginar. A necessidade de visualizar o mais precisamente possível as mediações simbólicas e o objeto constituído pelo milagre, sobretudo de visualizar a sua materialidade, a sua carnalidade, a sua humanidade. Porque o milagre só pode existir na relação dos contrários: o sagrado se troca com o profano, o propriamente material, para regenerá-lo e nessa troca, nesse toque, sacraliza o que foi tocado, promove a ressurreição do que estava morto, na morte parcial da doença, do ferimento, da dor.

Nessa troca, a fotografia também se reveste de sentido como momento singular do próprio sagrado.

Notas

1 Identifico-me com as mesmas preocupações teóricas de Elizabeth Edwards quanto à situação do trabalho fotográfico no limite dos campos específicos da Antropologia e da Fotografia. Cf. Elizabeth Edwards, "Border Practices: Photography and Anthropology" em Acts of faith: Brazilian contemporary photography (Oxford: BrazilConnects/Pitt Rivers Museum, 2001), pp. 11-14; Elizabeth Edwards, "Beyond the Boundary: A Consideration of the Expressive in Photography and Anthropology" em Marcus Banks e Howard Morphy (eds.) Rethinking visual anthropology (New Haven e Londres: Yale University Press, 1997), pp. 53-80. Interesso-me especial- 
mente pela interação de códigos nos vários limites que demarcam o território dos usos possíveis da fotografia e definem a sua polissemia. É nessa perspectiva que o sociólogo pode produzir uma sociologia do conhecimento visual. Uma esclarecedora revisão crítica e histórica do tema, em particular da relação entre o icônico e o indicial, encontra-se no ensaio de Philippe Dubois, "Da Verossimilhança ao Índice" em Philippe Dubois. O ato fotográfico e outros ensaios, tradução de Marina Appenzeller, $2^{\text {a }}$ edição (Campinas: Papirus Editora, 1998), pp. 23-56.

2 Mills assinala: “A imaginação sociológica permite ao seu possuidor compreender o cenário histórico mais amplo quanto ao seu significado para a vida interior e para a trajetória exterior da diversidade de indivíduos. Ela lhe permite ter em conta como os indivíduos, no tumulto da experiência cotidiana, estão com freqüência falsamente conscientes de suas posições sociais. [...] A imaginação sociológica nos permite captar a história e a biografia e a relação entre ambas na sociedade." Cf. C. Wright Mills. La imaginación sociologica, (Cidade do México-Buenos Aires: Fondo de Cultura Económica, 1961), pp. 25-26. Do mesmo modo, a meu ver, por motivações estéticas ou documentais, a imaginação fotográfica se manifesta na busca dos desconstrutores do visível, como ocorre com alguns dos fotógrafos cujas obras foram incluídas nessa mostra. É nessa perspectiva que o "falsamente consciente" pode ser revelado.

3 É útil aqui o lembrete de Adorno sobre o método na Sociologia: "Em geral, a objetividade da investigação social empírica é de método, não do investigado." Cf. Theodor W. Adorno. "La Sociología y la Investigación Empirica", em Max Horkheimer e Theodor W. Adorno. Sociologica, tradução de Víctor Sánchez de Zavala (Madri: Taurus Ediciones S.A., 1966), p. 277.

4 É o que nos sugere a sociologia fenomenológica, em particular a dramaturgia social de Goffman. Em especial, cf. Erving Goffman, A representação do eu na vida cotidiana, tradução de Maria Célia Santos Raposo, $6^{a}$ edição (Petrópolis: Vozes, 1995).

5 Cf. Henri Lefebvre. La présence et l'absence: contribution à la théorie des représentations (Paris: Casterman, 1980), p. 24.

6 Essas tensões têm sido a referência do tema do fantasioso e do onírico na sociologia. Bastide já havia indicado a estrutura básica de sua ocorrência ao constatar que "em nossa civilização - ocidental - estão cortadas as pontes entre a metade diurna e a metade noturna do homem". Cf. Roger Bastide. "Sociologia do Sonho" em Roger Caillois e G. E. von Grunebaum (orgs.) O sonho e as sociedades humanas (Rio de Janeiro: Livraria Francisco Alves Editora, 1978), p. 138. Fromm retoma o tema da consciência dividida ao distinguir "consciência de vigília" e "consciência de sonho". Cf. Erich Fromm. "Consciencia y Sociedad Industrial" em Erich Fromm et alii. La sociedad industrial contemporánea, tradução de Margarita Suzan Prieto e Julieta Campos (Cidade do México: Siglo XXI Editores, 1967), p. 4.

7 Salgado, por convicções ideológicas, recusa a interpretação de que sua fotografia seja mais do que fotografia documental e que tenha, portanto, qualquer orientação de natureza estética. Nos debates de que tem participado e em conversa pessoal que com ele tive durante a exposição "Êxodos", em São Paulo, ouvi dele a convicta afirmação de que é um repórter fotográfico. Pierre Verger, que fez da fotografia uma 
obra de arte sobre a África negra e o mundo que os escravos criaram nos dois lados do Atlântico, reconhecia que à medida que passara a ser definido como antropólogo e aceitara essa identidade, sua fotografia se empobrecera como obra de arte, tendendo para o deliberadamente documental. De fato, numa ampla exposição panorâmica e cronológica de sua obra, no Museu de Arte de São Paulo, era possível constatar o momento dessa inflexão e dessa perda.

8 Pierre Bourdieu (org.) Un art moyen: essai sur les usages sociaux de la photographie (Paris: Les Éditions de Minuit, 1965).

9 O tratamento da fotografia como coisa morta e da morte se choca com aspectos do seu uso popular como coisa viva e como fator de vivência, como ato de afirmação da vida. Tiago Santana, um dos fotógrafos aqui considerados, cujo olhar fotográfico quase iconoclasta é um dos fatores da importância antropológica de sua fotografia, surpreendeu-se, quando da realização de sua exposição Benditos, no Ceará, em 2000, ao constatar que "muitas vezes, quem literalmente percorria os caminhos da exposição chorava, se sentava em um canto e refletia ou rezava". Cf. "O Olhar Atento de Tiago Santana sobre os 'Benditos"', O Estado de S. Paulo (Caderno 2), 17 de abril de 2001. Ocorre-me, também, outro fato relacionado com a "vida" da fotografia. Um dia, por mãos de missionários católicos, chegou à única aldeia subsistente dos índios tapirapé, no Brasil central, um exemplar do denso e volumoso livro que sobre eles escrevera o etnólogo Herbert Baldus. Cf. Herbert Baldus. Tapirapé: tribo tupi no Brasil central (São Paulo: Companhia Editora Nacional/Editora da Universidade de São Paulo, 1970). A pesquisa de Baldus fora feita entre os anos 1930 e 1940, quando os tapirapé estavam sendo contatados pelos brancos. Seu livro é amplamente ilustrado com fotografias dessa época, quando os tapirapé ainda se distribuíam por mais de uma aldeia e ainda não haviam sido dizimados pelos índios kayapó, seus inimigos tradicionais. Ao verem as fotos no livro, os tapirapé iniciaram o pranto ritual, o choro de acolhimento dos que partiram e voltam. Como fizeram, nos anos 1970, quando reencontraram na floresta uma família de seus compatriotas extraviados e perdidos desde o último ataque kayapó, muitos anos antes. Creio que o uso do retrato fotográfico na macumba ou na feitiçaria é outra indicação da força que alguns grupos sociais reconhecem a fotografia como representação viva, como equivalente, mais do que como mera figuração e semelhança.

10 Cf. Peter L. Berger e Thomas Luckmann. The social construction of reality: a treatise in the sociology of knowledge (Nova York: Anchor Books, 1967).

11 Cf., especialmente, Karl Mannheim. Ideología y utopia: introducción a la sociología del conocimiento, tradução de Salvador Echavarría (Cidade do México: Fondo de Cultura Económica, 1941).

12 Exposição realizada no Ashmolean Museum of Art and Archeology, em Oxford (Inglaterra), de 25 de outubro de 2001 a 3 de fevereiro de 2002, reunindo obras de Adenor Gondim, Antonio Saggese, Christian Cravo, José Bassit e Tiago Santana. A exposição desenvolveu-se simultaneamente com a exposição Opulence and Devotion: Brazilian Baroque Art.

13 Alguns dos fotógrafos que participam da exposição estão presentes também em Maria 
Luiza Melo Carvalho. Novas travessias: contemporary Brazilian photography (Londres e Nova York: Verso, 1996).

14 Neste texto, refiro-me principalmente às fotografias reproduzidas no catálogo da exposição, publicado sob o título Acts of faith: Brazilian contemporary photography (Oxford: BrazilConnects/Pitt Rivers Museum, 2001).

15 Além das fotos desse autor contidas no catálogo da exposição, remeto o leitor, também, ao livro de Tiago Santana. Benditos (Fortaleza: Tempo d'Imagem, 2000).

16 Uso a concepção de equipamento de identificação no sentido em que a propõe Erving Goffman, Internados: ensayos sobre la situación social de los enfermos mentales, tradução de María Antonia Oyuela de Grant (Buenos Aires: Amorrortu Editores, 1970), p. 32. Goffman desenvolve essa idéia em conexão com a análise de processos interativos desidentificadores. No caso presente, as pessoas incorporam o equipamento de identificação de outro grupo social, motivadas pelo intuito de se apropriar do carisma nele supostamente contido.

17 Cf. Antonio Crocco. Gioacchino da Fiore e il Gioachimismo (Nápoles: Liguori Editori, 1976).

18 Cf. Antônio Vieira. Apologia das coisas profetizadas, tradução do latim de Arnaldo Espírito Santo, organização e fixação do texto de Adma Fadul Muhana (Lisboa: Edições Cotovia, 1994), pp. 177-203.

19 A fotografia dos "atos de fé", numa situação social e religiosa como a brasileira, amplamente permeada por significações e orientações sociais marcadamente milenaristas ou messiânicas, o que é especialmente claro no caso do profetismo do padre Cícero, não pode ser "lida" e interpretada sem referência à dimensão utópica que lhe é própria. Tomo utopia no sentido em que a define Karl Mannheim: "Somente serão designadas com o nome de utopias aquelas orientações que transcendem a realidade quando, ao passar ao plano da prática, tendam a destruir, parcial ou completamente, a ordem de coisas existente em determinada época”. Cf. Karl Mannheim. Ideología y utopia, p. 169. Nesse caso, sem a contextualização histórica e antropológica dos cenários, pessoas e situações sociais fotografados, fica impossível recuperar na leitura documental da fotografia suas verdadeiras revelações, especialmente os indícios de desconstrução antropológica e sociológica da imagem fotográfica.

20 Há uma concepção historicamente mais ampla do hibridismo latino-americano em Néstor García Canclini, Culturas hibridas: estrategias para entrar y salir de la modernidad (Cidade do México: Editorial Grijalbo, 1990), pp. 65-93.

21 Cf. A. Saggese. À sua imagem e semelhança (Curitiba: Fund. Cultural de Curitiba, 1995).

22 Em suas reflexões sobre o embate entre fotografia documental e fotografia expressiva, Elizabeth Edwards trata de modo consistente e sugestivo do lugar do visível e do invisível na fotografia, em particular retornando ao tema do punctum proposto por Barthes. Cf. Elizabeth Edwards, "Beyond the Boundary: A Consideration of the Expressive in Photography and Anthropology", pp. 58-59.

23 Cf. Antonio Saggese (Museu de Arte de São Paulo/Museu de Arte Moderna do Rio de Janeiro, 1991). 
24 Em seu ensaio sobre a fotografia, Barthes retorna diversas vezes ao tema da morte. No meu modo de ver, porém, a ausência de referências antropológicas comparativas em seu estudo circunscreve essa associação a uma visão da moderna classe média e seu peculiar secularismo. Barthes, aliás, é de origem protestante, embora assinale sua educação artística católica, o que torna compreensível esse aspecto de sua concepção da fotografia como uma espécie de idolatria dos vivos em relação aos mortos. É significativo que as ilustrações de seu texto sejam sobretudo retratos. Cf. Roland Barthes. A câmara clara: nota sobre a fotografia, tradução de Júlio Castañon Guimarães (Rio de Janeiro: Editora Nova Fronteira, 1984), pp. 53, 106, 112-113, 137-138. No caso das fotografias exibidas em Acts of Faith, estamos em face da realidade de populações ainda fortemente vinculadas ao mundo pré-capitalista e a uma religiosidade bem diferente da que constitui a referência de Barthes, uma religiosidade que não instituiu ainda a radical separação entre a vida e a morte. Mesmo que, para as populações presentes nas fotos da exibição aqui comentada, a morte seja uma referência dos atos e não das fotos, estamos em face de uma outra dimensão da morte: a morte como mediação dialética de uma concepção de vida eterna e de utopia. Portanto, a vida como realidade mais forte que a realidade da morte. As fotos nos falam da esperança de vitória do homem sobre sua própria morte e não da angústia do homem moderno em face do fim inevitável, da consumação definitiva, tema, aliás, de uma breve e significativa consideração de Weber. Cf. Max Weber. Ciência e política: duas vocações, tradução de Leonidas Hegenberg e Octany Silveira da Mota (São Paulo: Editora Cultrix, 1970), p. 31.

25 Cf. Luís da Câmara Cascudo. Dicionário do folclore brasileiro (Brasília: Instituto Nacional do Livro, 1972), p. 199.

26 Em sua definição de punctum, Barthes se refere ao acaso que punge por oposição a studium (Roland Barthes, op. cit., p. 46). No entanto, a definição de acaso é aí imprecisa. Ela poderia legitimamente incluir a intuição antropológica do fotógrafo nãoantropólogo, isto é, do autor de fotografia artística ou documental que incorpora à sua fotografia o que o cientista social pode ler e interpretar como decodificador, como revelador da etnografia que há na fotografia não intencionalmente etnográfica. É o caso dos cinco autores dessa exposição. Na sua concepção de "inconsciente ótico", Benjamin assinala com precisão esse ponto de referência fundamental para a leitura da fotografia pelas ciências sociais. Cf. Walter Benjamin, "Pequena História da Fotografia" em Walter Benjamin. Obras escolhidas, v. 1, $7^{\text {a }}$ edição, tradução de Sérgio Paulo Rouanet (São Paulo: Editora Brasiliense, 1994), p. 94. Schaeffer reitera a constatação da "amplificação do universo visual que devemos ao dispositivo fotográfico". Cf. Jean-Marie Schaeffer. A imagem precária: sobre o dispositivo fotográfico, tradução de Eleonora Bottmann (Campinas: Papirus Editora, 1996), pp. 20-21. Samain, comentando Barthes quanto ao punctum, vai, enfim, ao essencial: "Ele é o sentido obtuso, um sentido que não pertence mais ao domínio da língua, mas que se confessa na abertura de uma ferida. É a ausência e o silêncio de todo sentido que, paradoxalmente, provoca um novo sentido, este grito íntimo, intenso, necessário a seres vivos, confrontados naquilo de que sempre a fotografia fala: a vida e a morte, o tempo e a existência." Cf. Etienne Samain, "Um Retorno à Câmara Clara: Roland Barthes e a Antropologia Visual" em Etienne Samain (org.) Ofotográfico (São Paulo: Hucitec/CNPq, 1998), p. 131. 
27 Euclides da Cunha já havia observado na guerra sertaneja e religiosa de Canudos (1896-1897) que os beatos "vestem roupas azuis, cingidas as cinturas por cordas de linho alvíssimo; não variam nunca este uniforme consagrado". Cf. Euclydes da Cunha. Canudos: diário de uma expedição (Rio de Janeiro: Livraria José Olympio Editora, 1939), pp. 38-39.

28 Tomo como referência dois textos fundamentais sobre o tema. Cf. Robert A . Nisbet. "Sociology as an Art Form" em Tradition and revolt (Nova York: Vintage Books, 1970), pp. 143-162; e Robert Nisbet. Sociology as an art form (Londres: Oxford University Press, 1976).

José de Souza Martins é professor titular de Sociologia da Faculdade de Filosofia, Letras e Ciências Humanas da Universidade de São Paulo; fellow de Trinity Hall e professor titular da Cátedra Simón Bolivar da Universidade de Cambridge (1993-94); e membro da Junta de Curadores do Fundo Voluntário das Nações Unidas Contra as Formas Contemporâneas de Escravidão. Dentre outros livros, é autor de Reforma Arária - o impossível diálogo (São Paulo: Edusp, 2000). 
FOTOGRAFIAS (PELA ORDEM)

Foto 1: Antonio Saggese Pirapora do Bom Jesus, São Paulo, 1992 


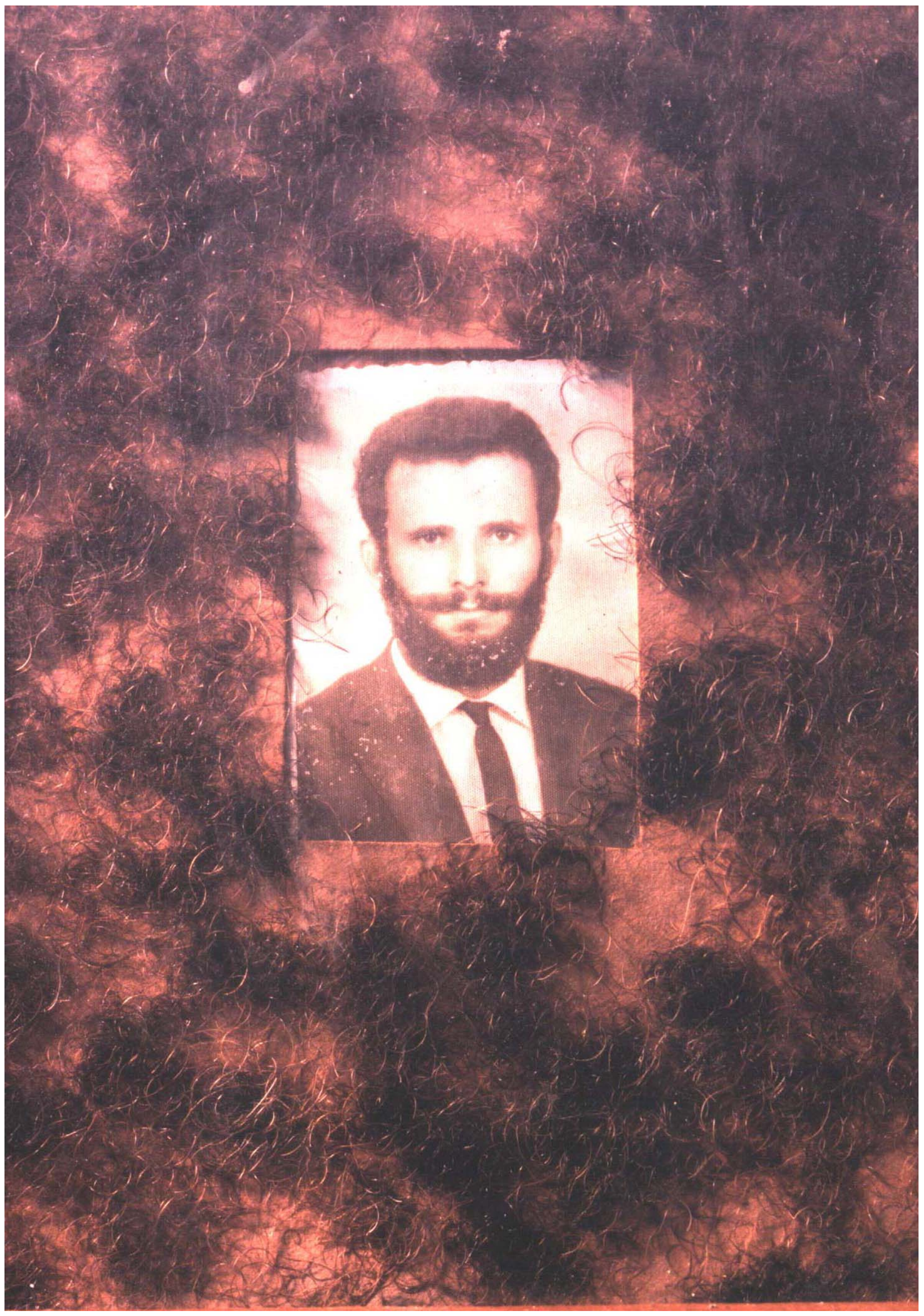




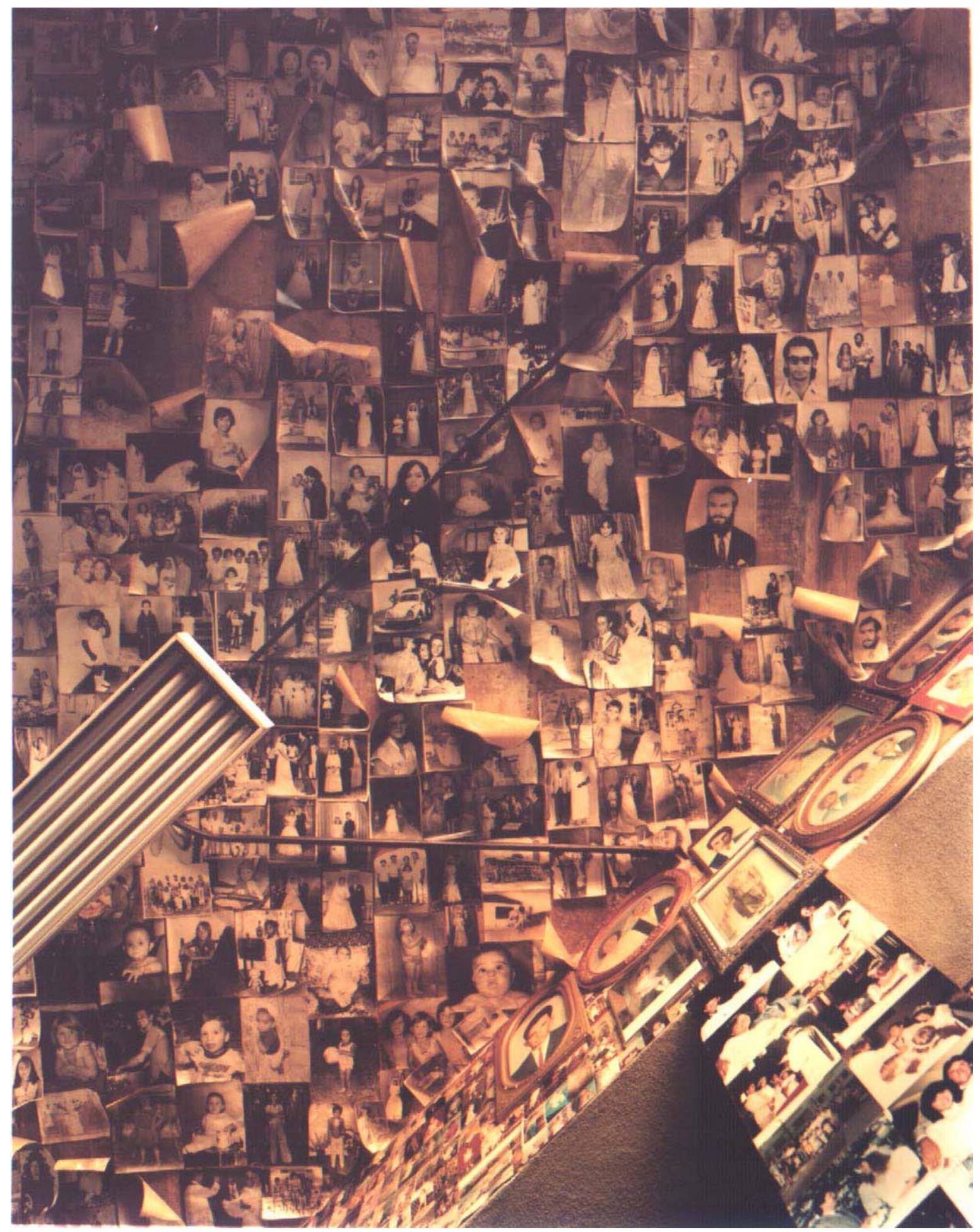

Foto 2: Antonio Saggese

Aparecida do Norte, São Paulo, 1992 


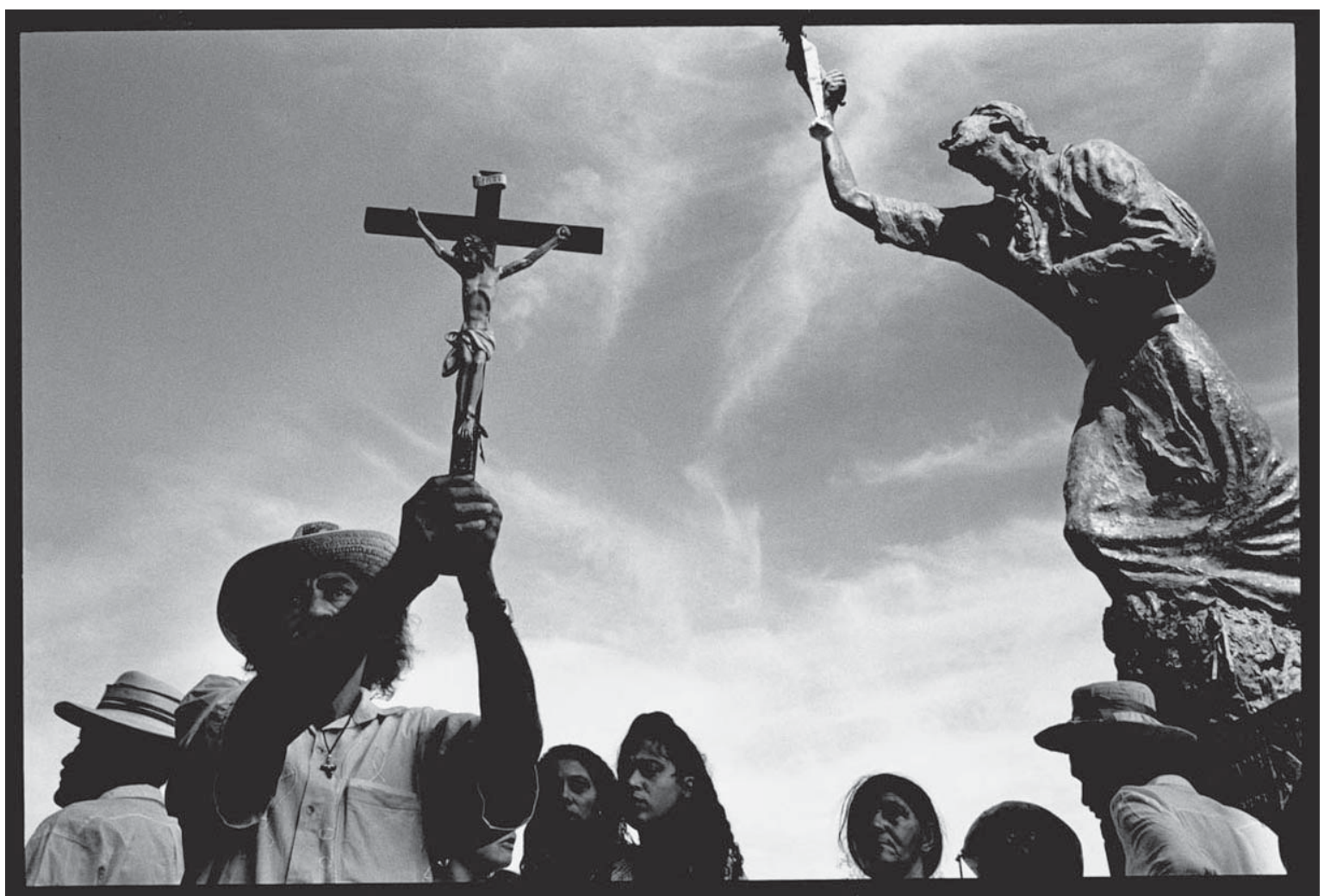

Foto 3: Christian Cravo - Bom Jesus da Lapa, Bahia, 1998

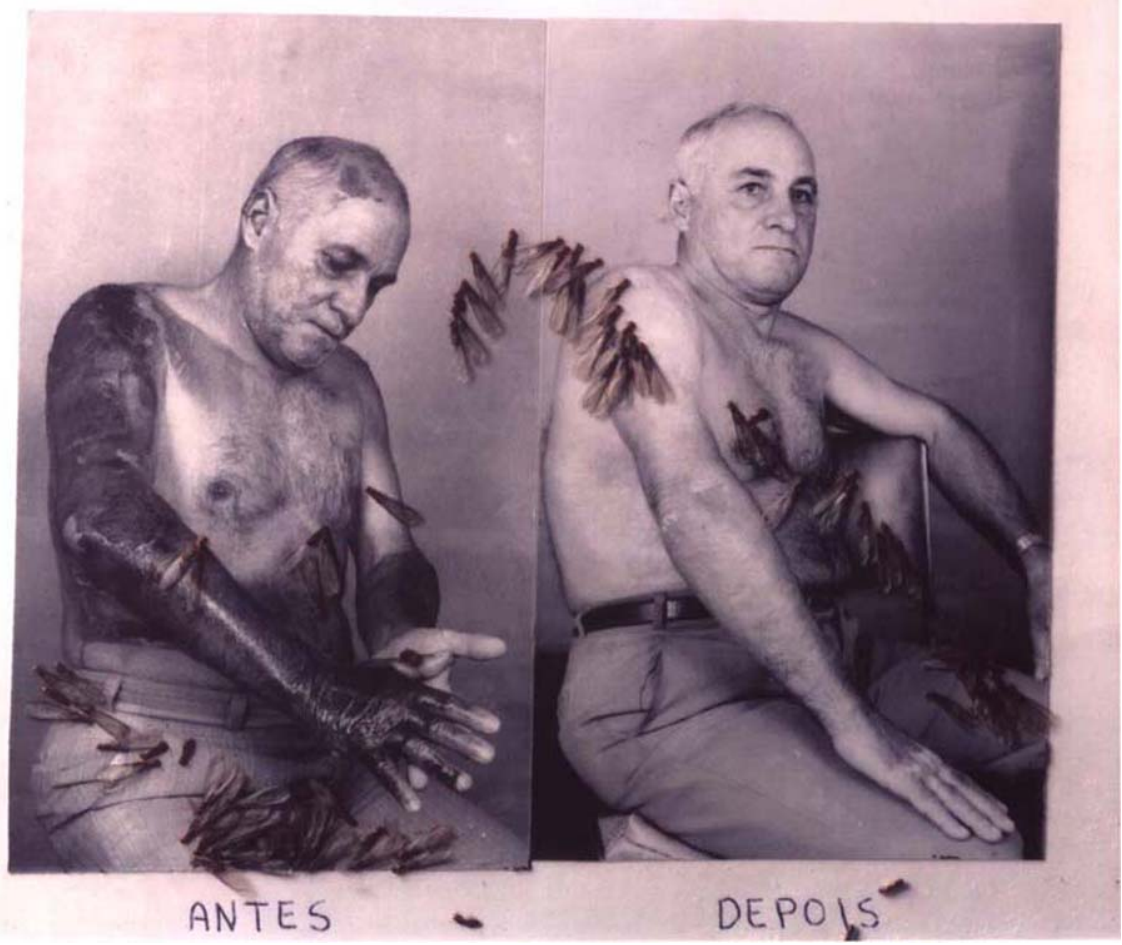

Foto 4: Antonio Saggese - Aparecida do Norte, São Paulo, 1992 


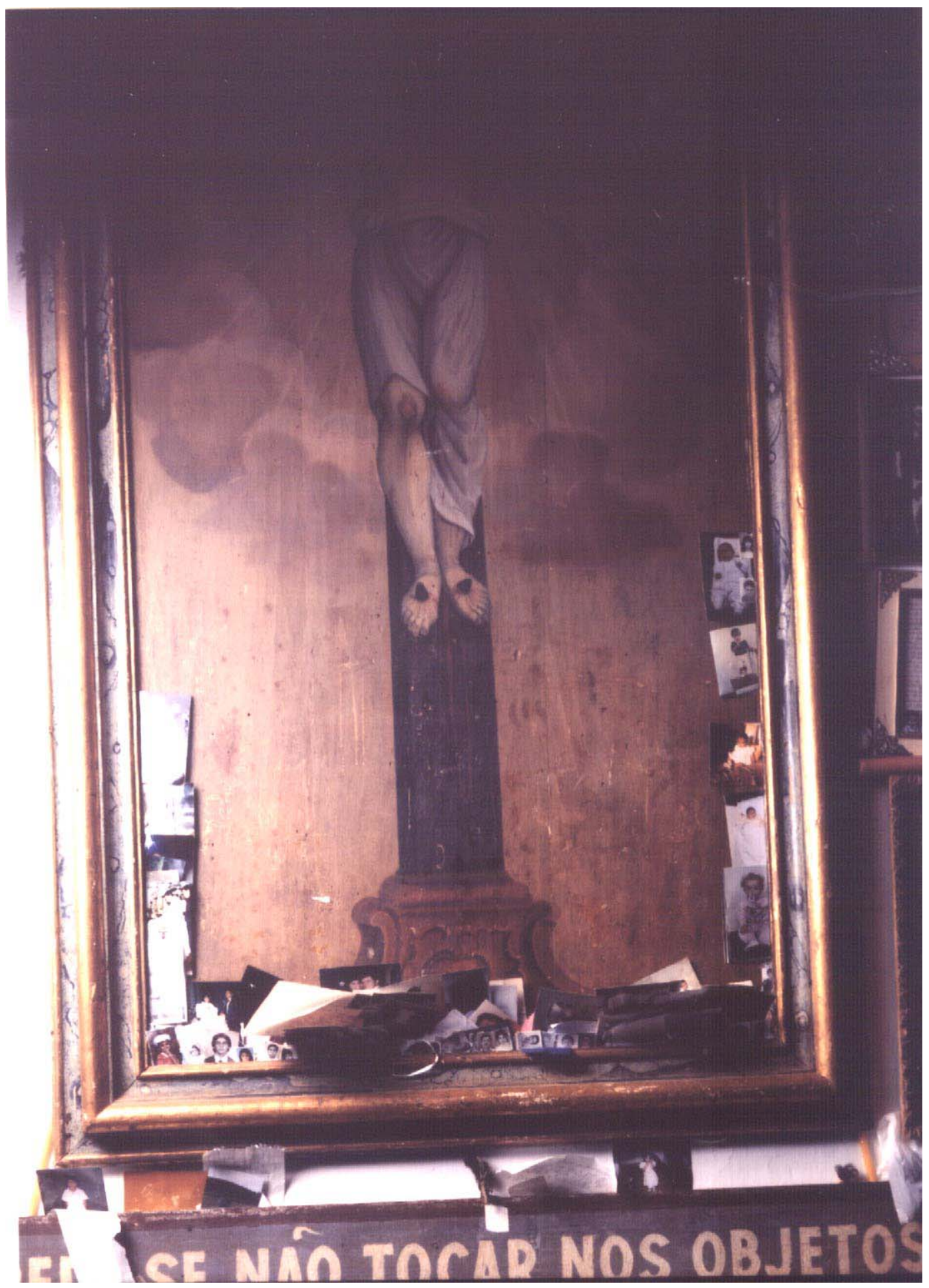

Foto 5: Antonio Saggese

Congonhas do Campo, Minas Gerais, 1992 


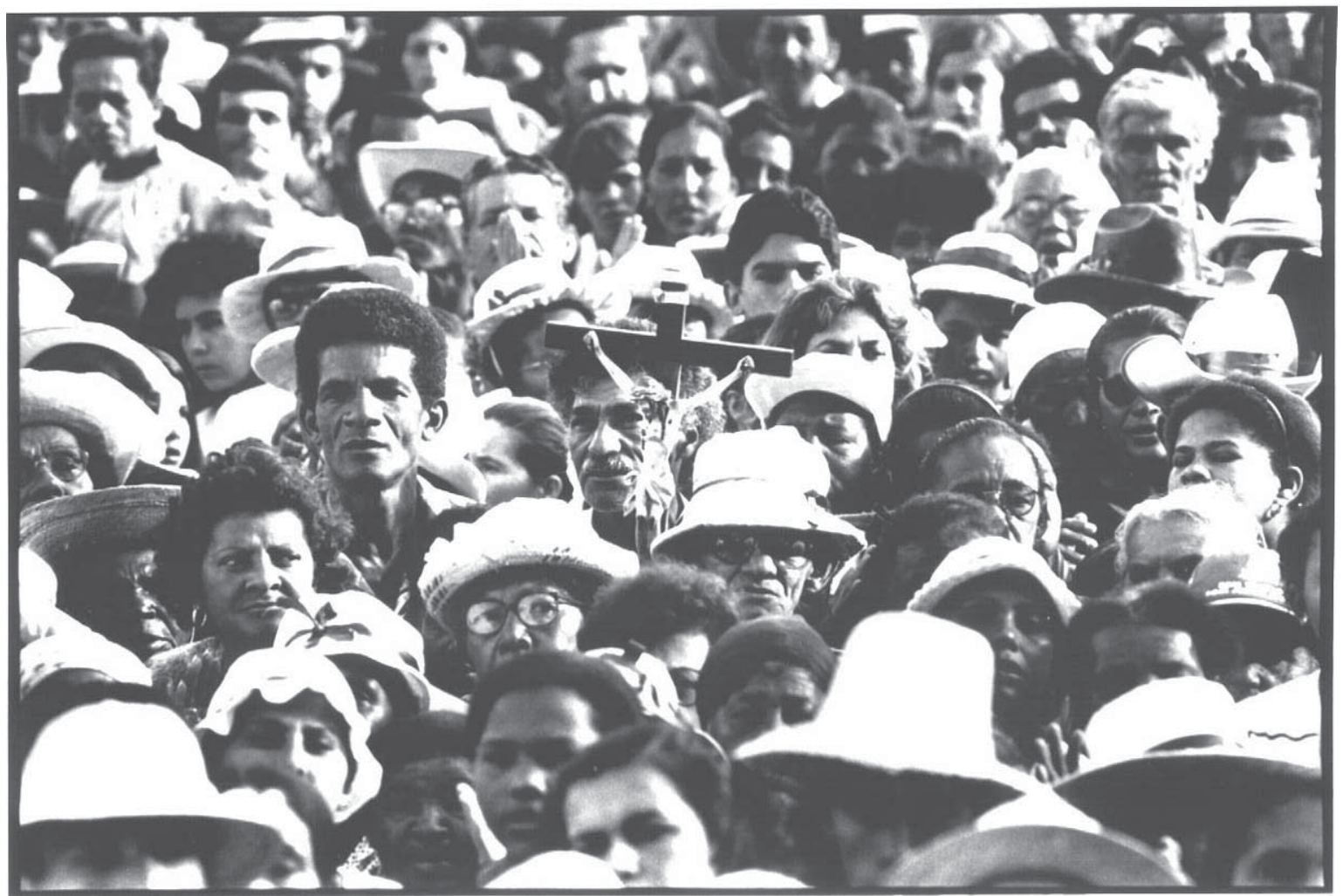

Foto 6: José Bassit - Festa do Santuário, Bom Jesus da Lapa, Bahia, 2000

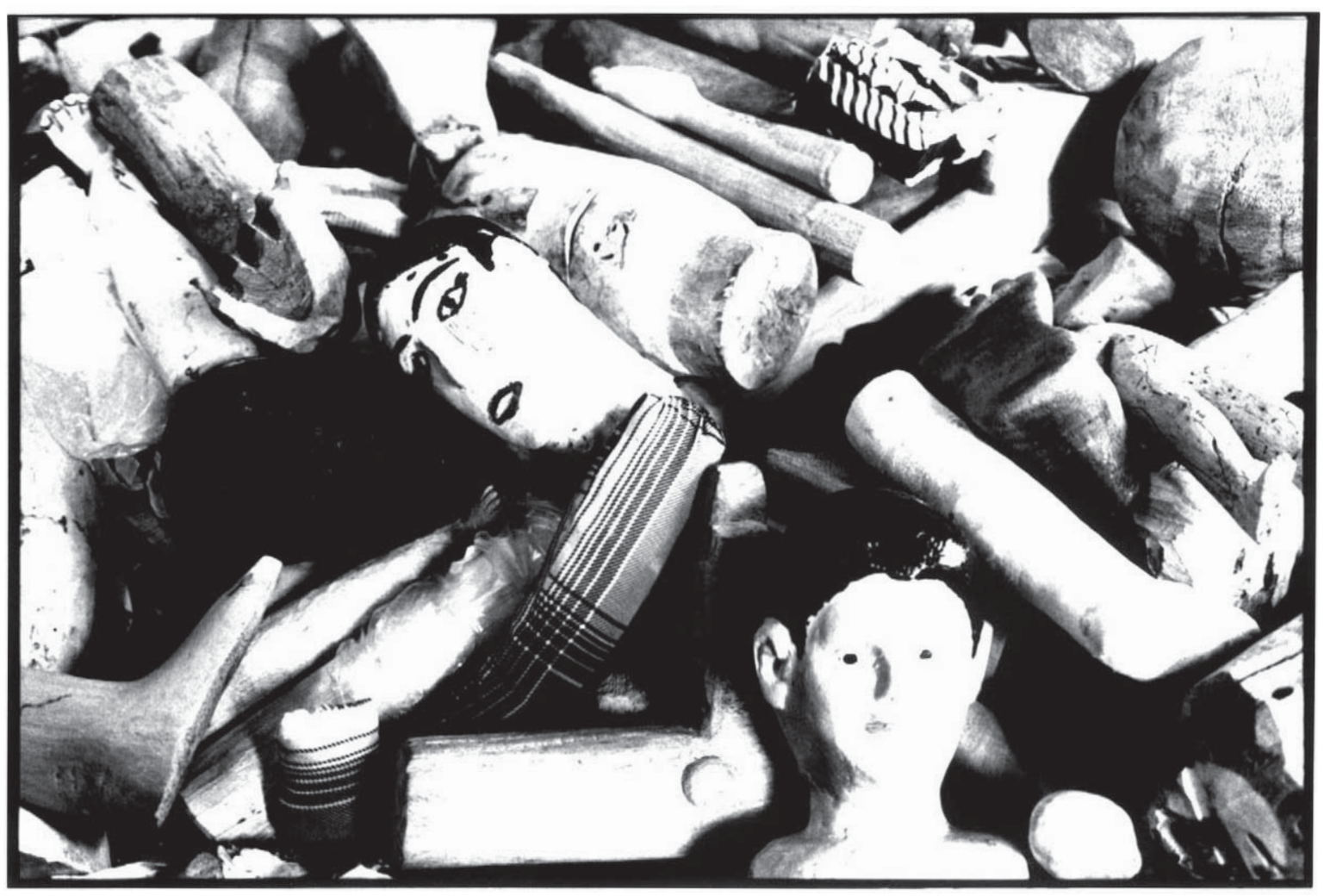

Foto 7: José Bassit - Ex-votos, Canindé, Ceará, 2000 


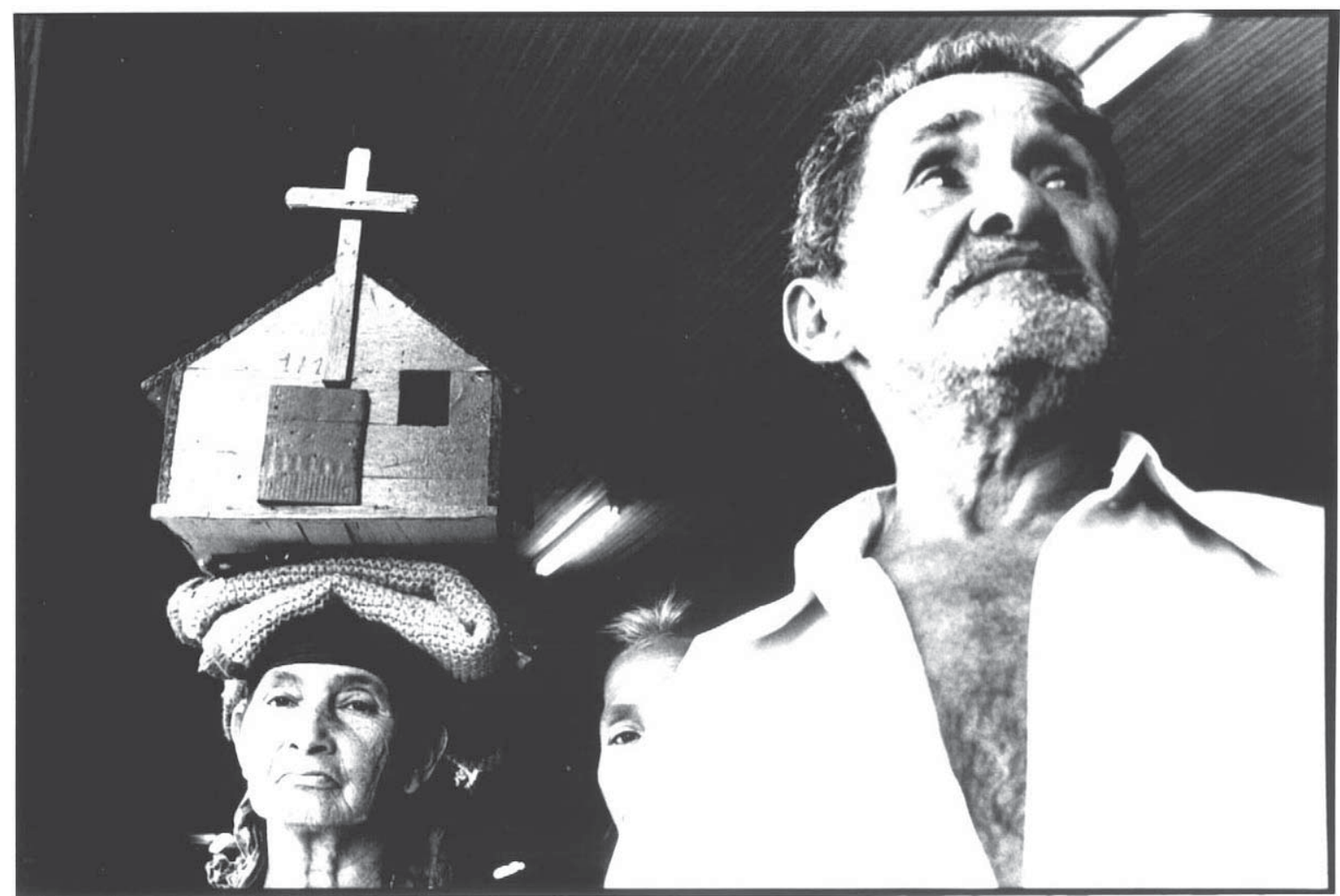

Foto 8: José Bassit - Canindé, Ceará, 2000

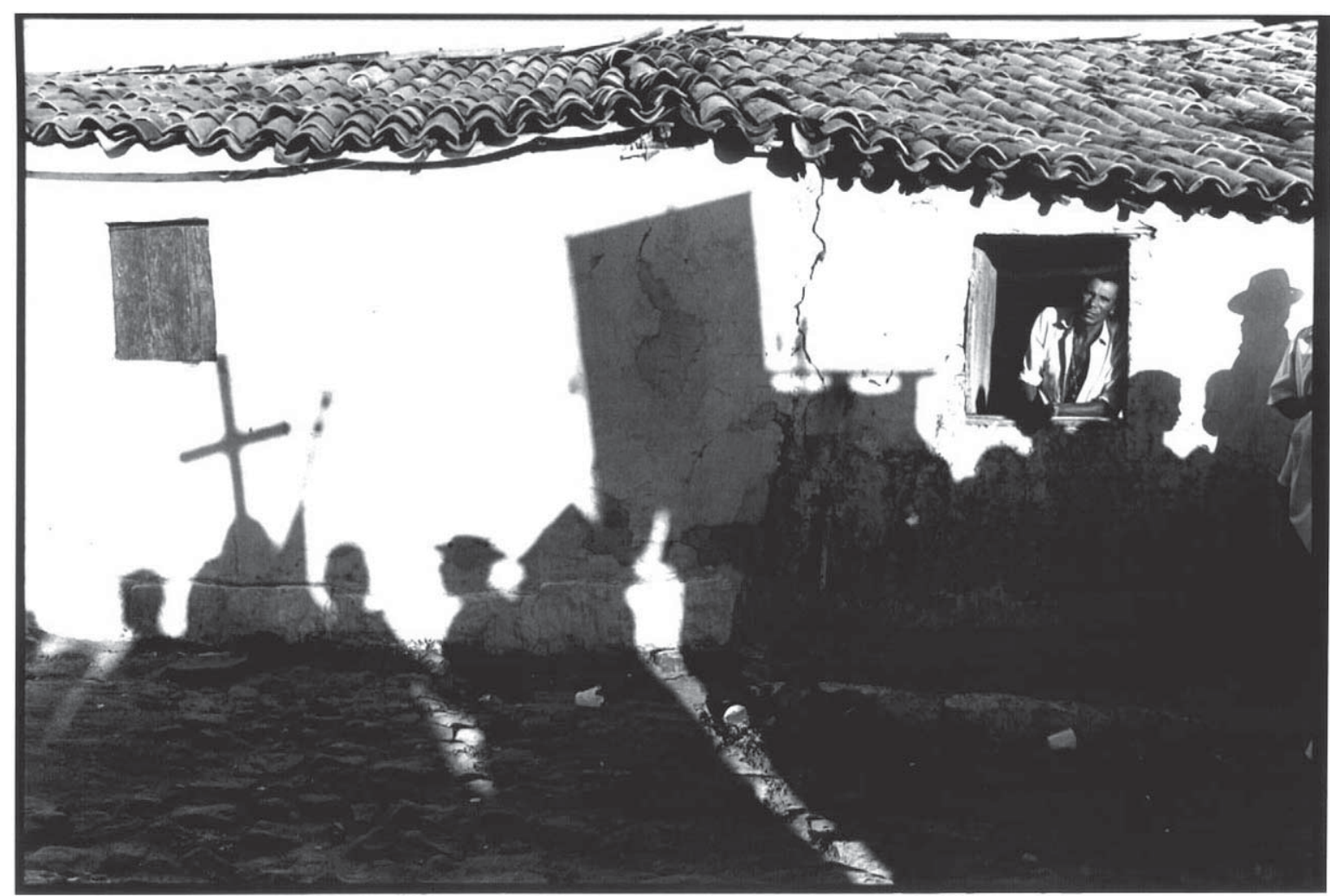

Foto 9: José Bassit - Procissão, Juazeiro do Norte, Ceará, 2000 


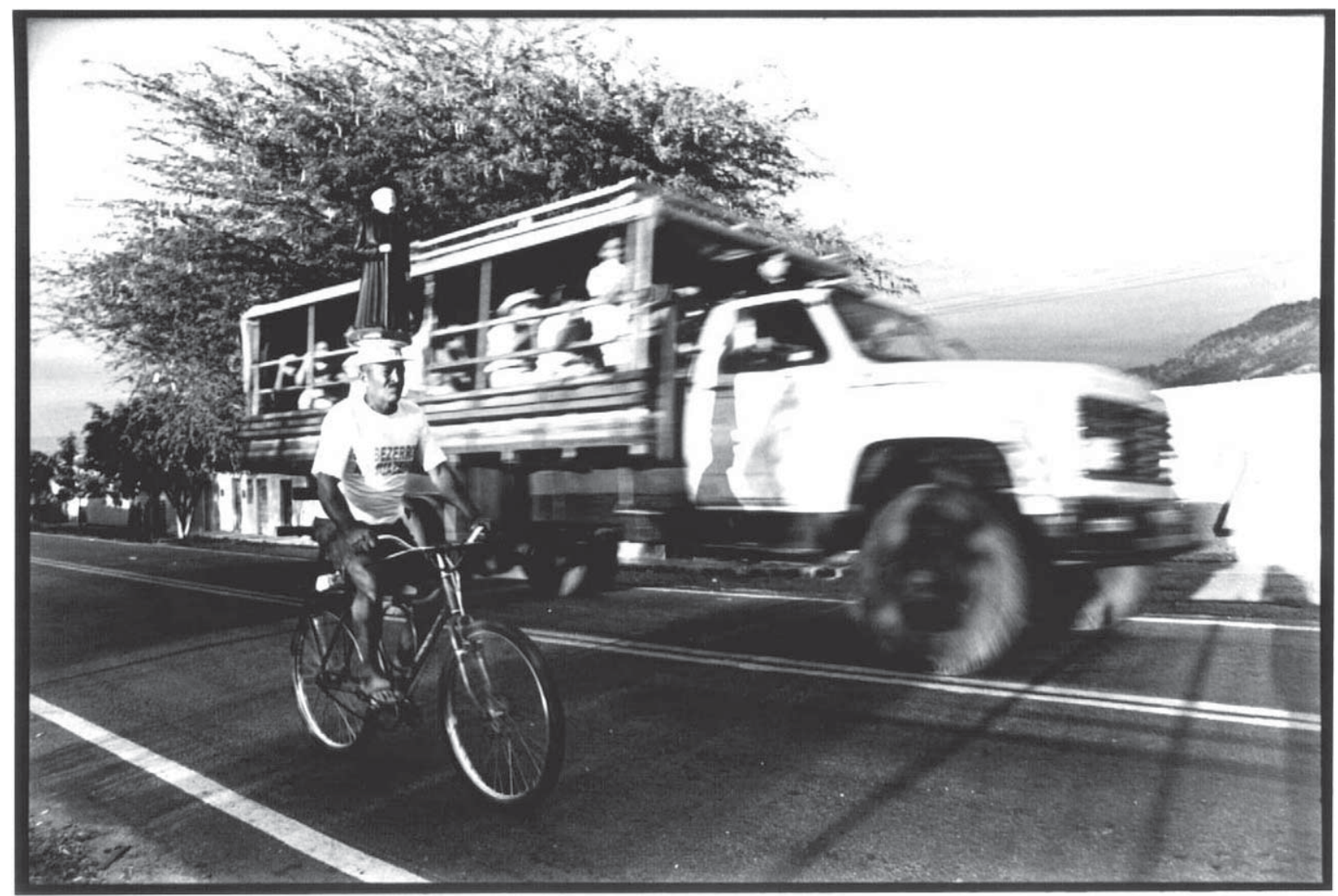

Foto 10: José Bassit - Juazeiro do Norte, Ceará, 2000

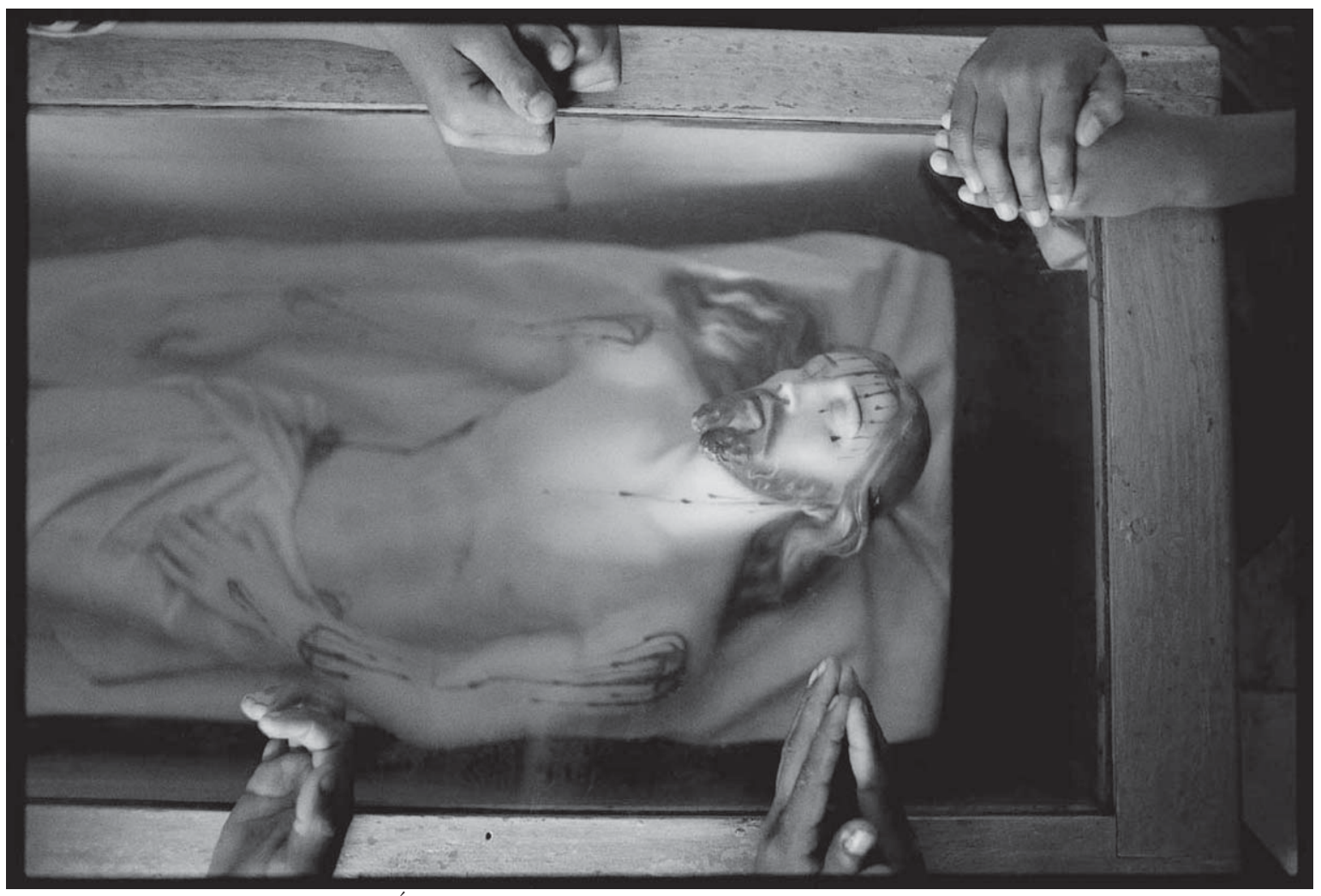

Foto 11: Christian Cravo - Índios Kiriri rezando, Mirandela, Bahia, 1993 


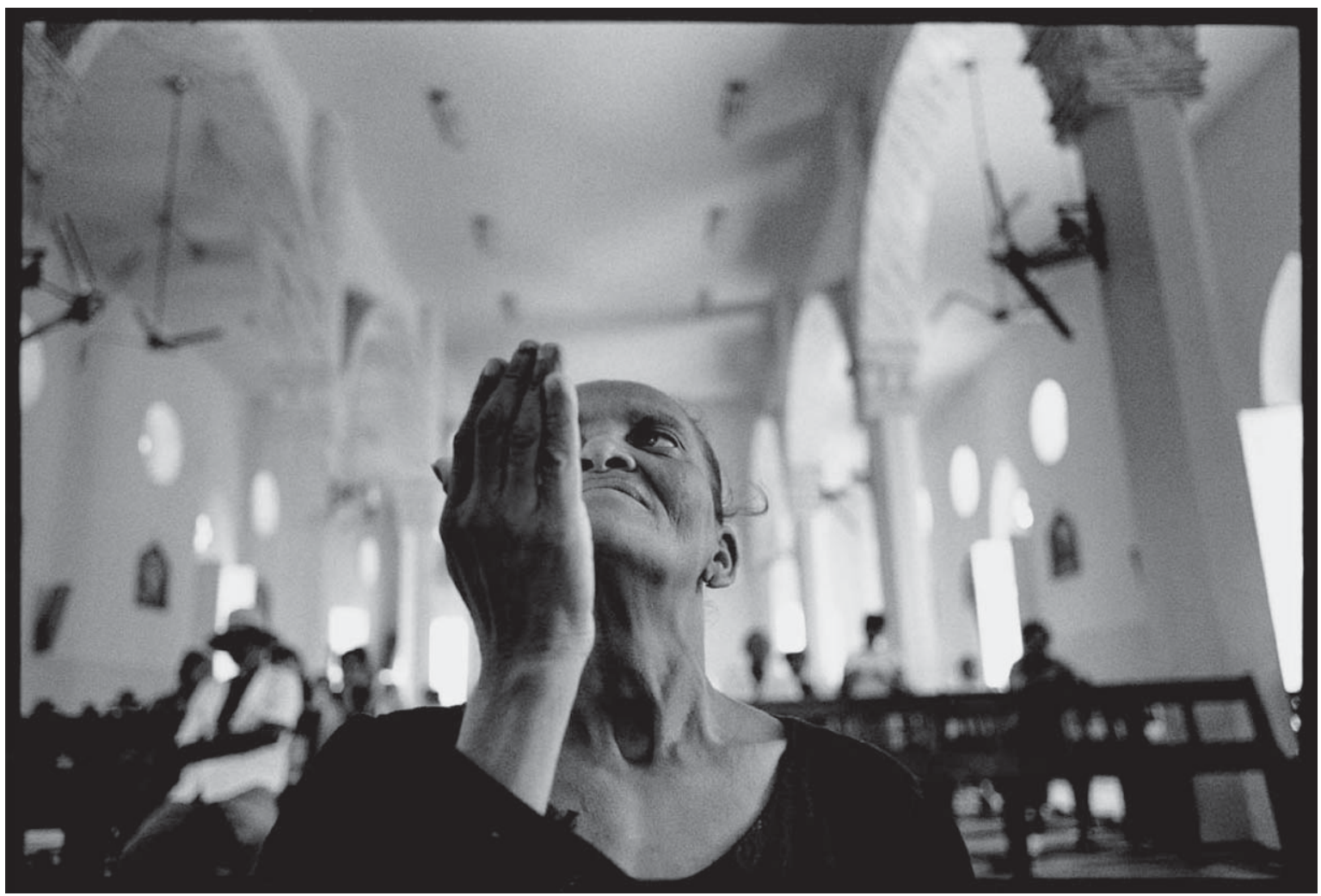

Foto 12: Christian Cravo - Juazeiro do Norte, Ceará, 2000

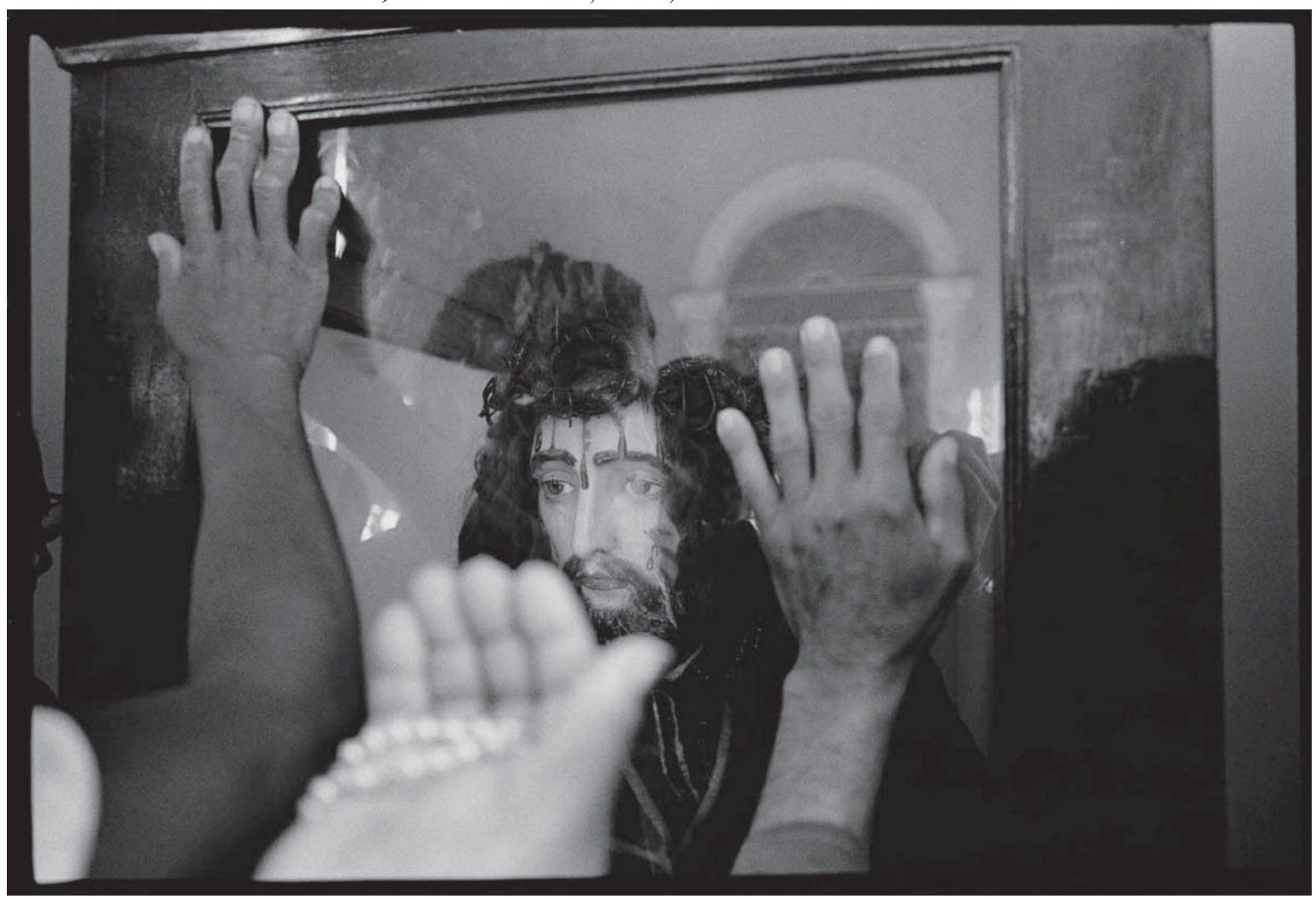

Foto 13: Christian Cravo - São Francisco de Canindé, Ceará, 1999 


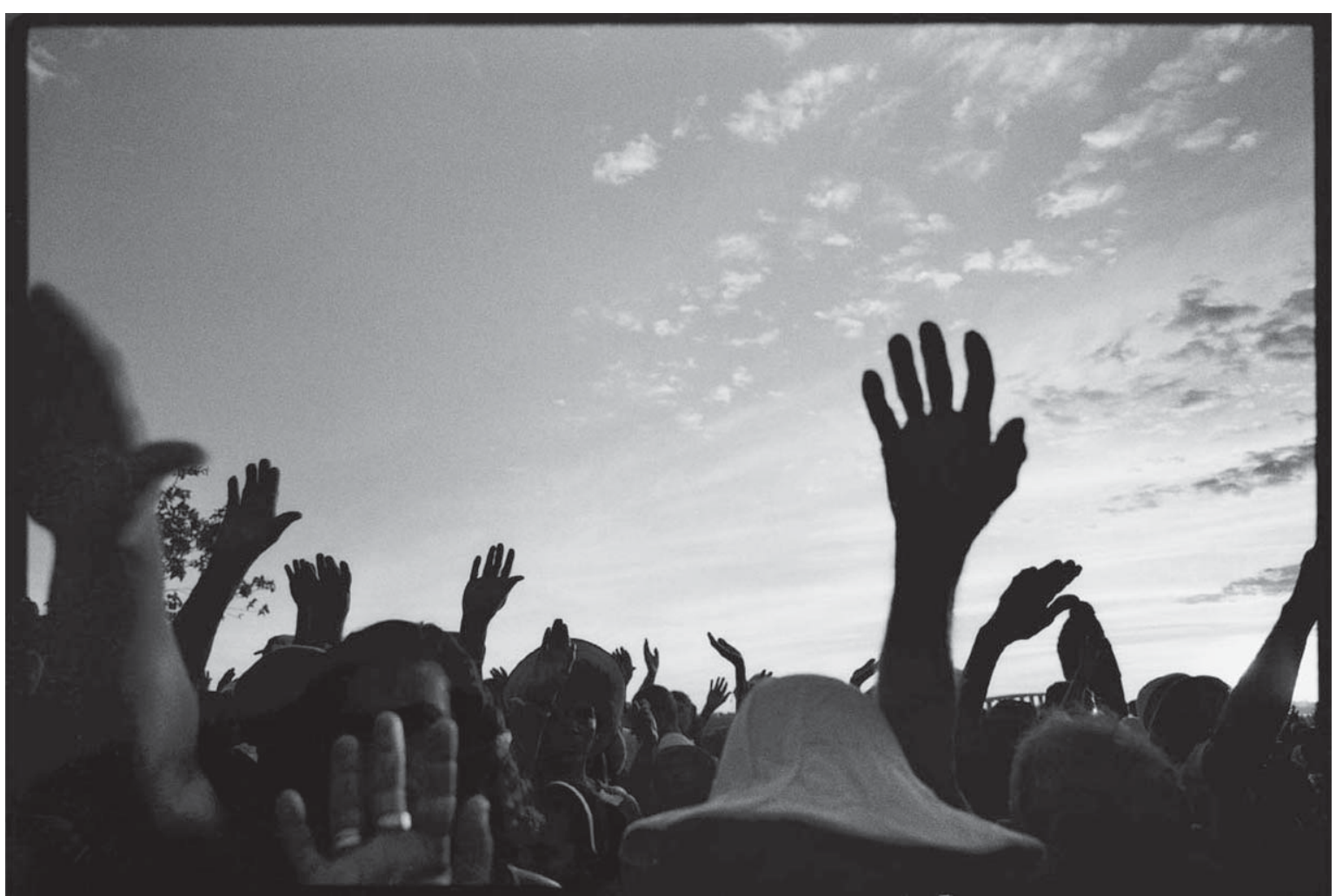

Foto 14: Christian Cravo - Bom Jesus da Lapa, Bahia, 2000

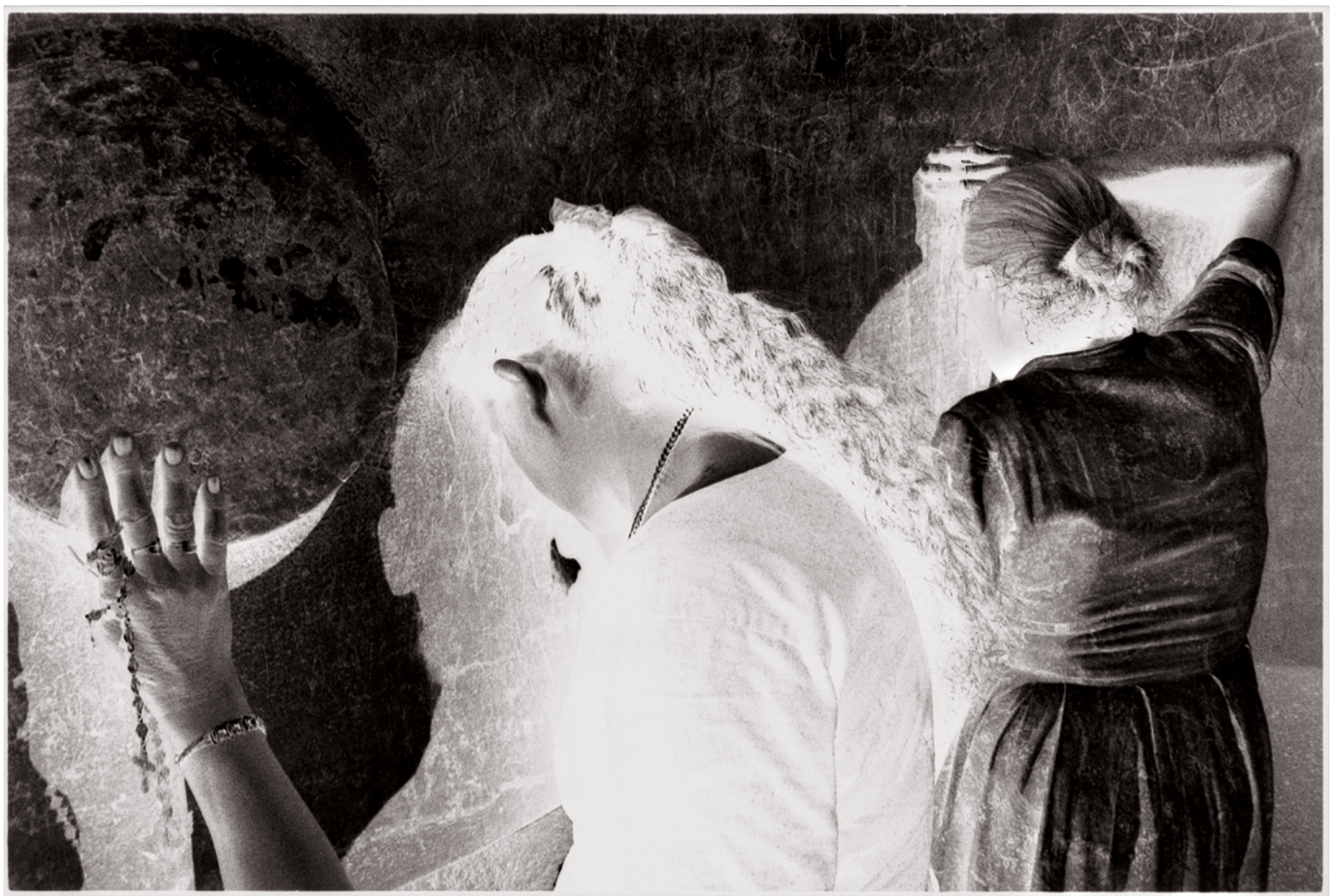

Foto 15: Tiago Santana - Juazeiro do Norte, Ceará, 1993 


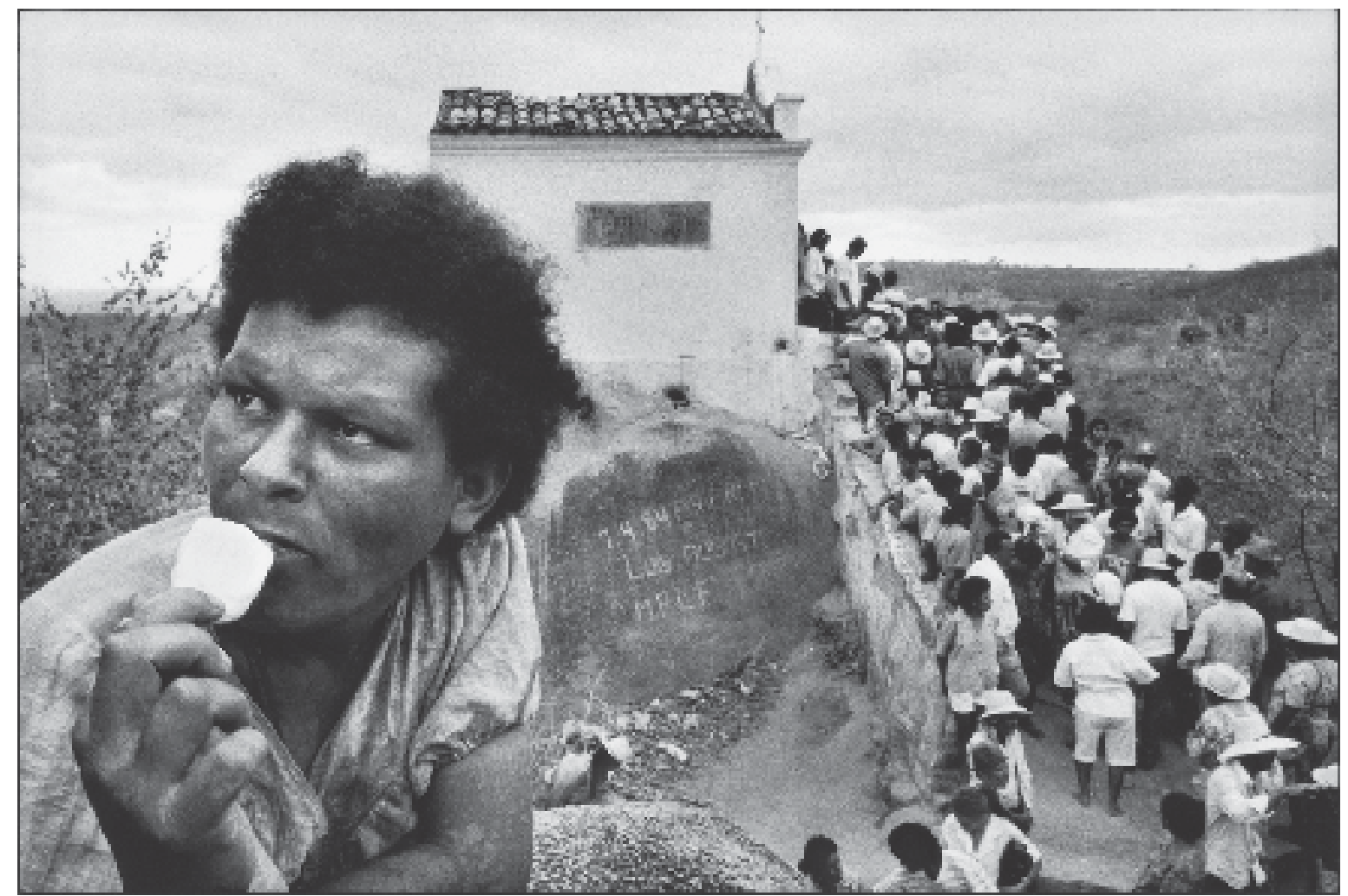

Foto 16: Tiago Santana - Juazeiro do Norte, Ceará, 1995

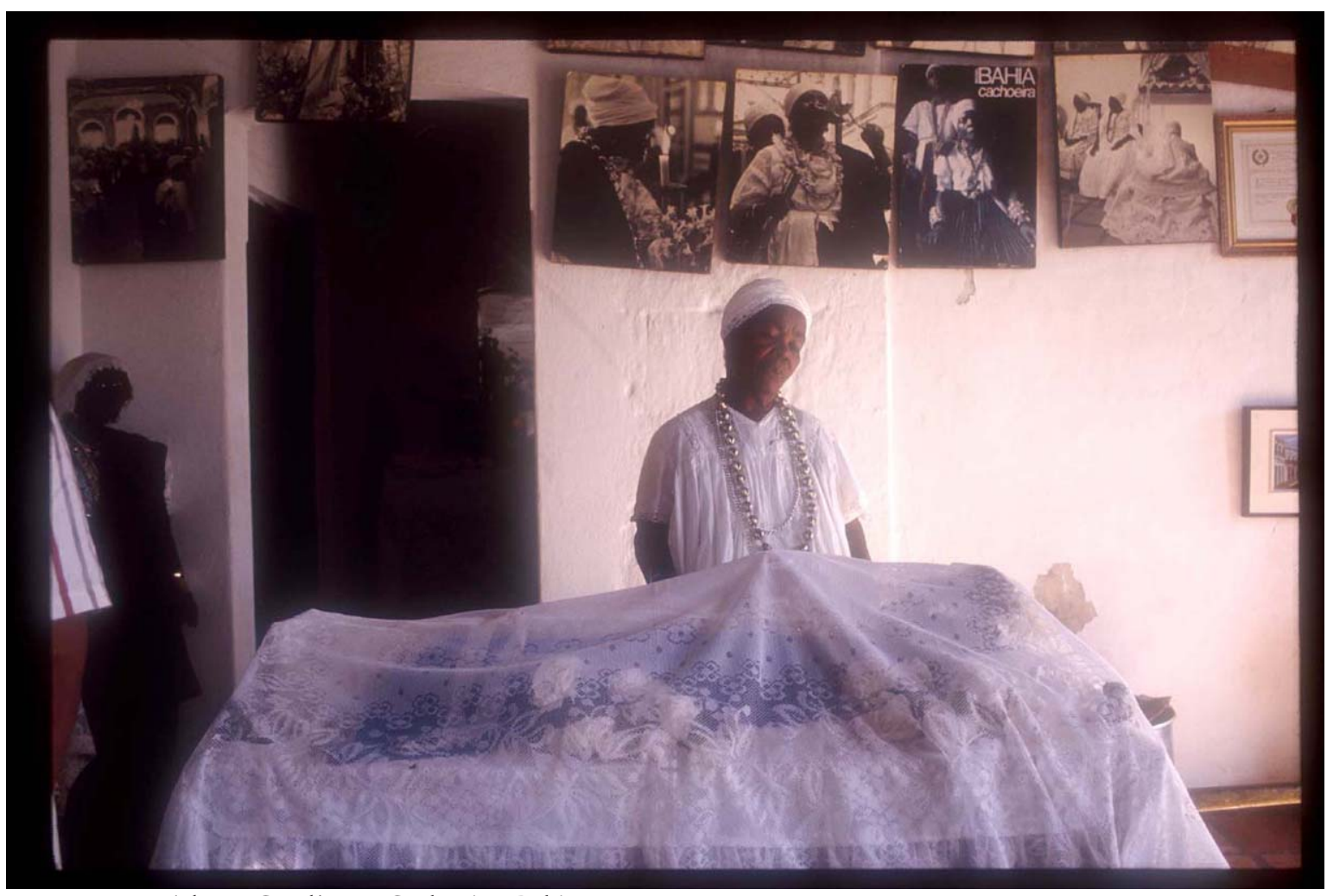

Foto 17: Adenor Gondim - Cachoeira, Bahia, 1998 